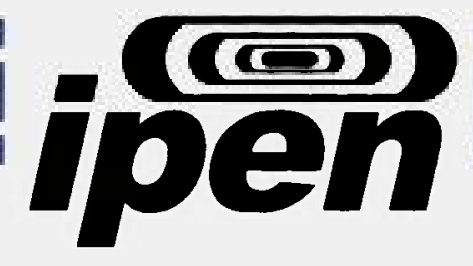

AUTARQUIA ASSOCIADA À UNIVERSIDADE DE SÃO PAULO

\title{
ESTUDO DOS EFEITOS DA TERAPIA FOTODINÂMICA EM PERIODONTITE INDUZIDA EM RATOS
}

\section{AÉCIO MASSAYOSHI YAMADA JÚNIOR}

Tese apresentada como parte dos requisitos para obtenção do Grau de Doutor em Ciências na Área de Tecnologia Nuclear - Materiais.

Orientadora:

Profa. Dra. Martha Simões Ribeiro 


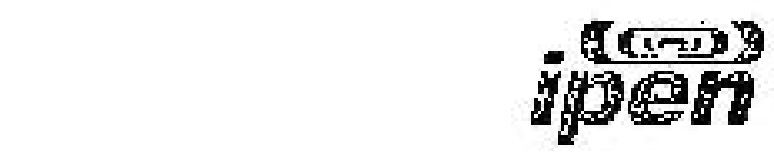

Instituto de Pesquisas Energéticas e Nucleares AUTARQUIA ASSOCIADA À UNIVERSIDADE DE SÃO PAULO

Estudo dos efeitos da terapia fotodinâmica em periodontite induzida em ratos

Aécio Massayoshi Yamada Júnior

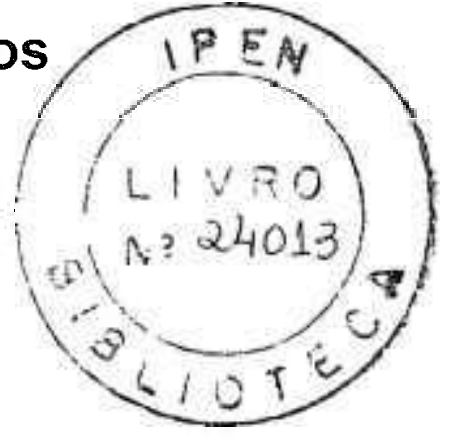

Tese apresentada como parte dos requisitos para obtenção do titulo de Doutor em Ciências na Área de Tecnologia Nuclear - Materiais 
DEDICATÓRIA

A meus pais, Aécio e Yossie, à minha irmã, Alessandra à Adriana 
À Profa. Dra. Martha Simões Ribeiro, orientadora e amiga, pelo meu crescimento tanto profissional quanto pessoal. Obrigado também à sua família, que por muitos momentos partilhamos de sua companhia.

À Profa. Dra. Silvana Cai, pela acolhida em seu laboratório, direcionando meus primeiros passos neste vasto mundo microbiológico.

Ao Prof. Dr. Nelson Villa, por sua acolhida no laboratório de histologia da UNISA.

À Profa. Dra. Márcia Alves Pinto Mayer, pelas importantes sugestões e colaborações dadas na realização deste trabalho.

À Profa. Dra. Denise Maria Zezell, pelo acompanhamento e preocupação durante toda a minha estada no Centro de Lasers e Aplicações (CLA).

Ao Prof. Dr. Edgar Yuji Tanji, amigo e primeiro orientador, responsável pela minha formação e admiração pela pesquisa.

Ao Prof. Dr. Silvio Issao Myake, que muito contribuiu na minha formação, pelas oportunidades dadas e principalmente pela amizade ao longo destes anos.

Aos amigos Luís Cláudio Suzuki e Renato Araújo Prates, que foram meus braços direito, durante todas as fases deste trabalho, me estimulando a seguir em frente.

Aos amigos de laboratório: Aguinaldo, Cris, Dani, Daniel e Silvia, pelo carinho e companheirismo. 
Aos amigos do CLA: Claudia, Ilka, Melissa, Patrícia, Tiago e Alessandro pelo apoio.

A Profa. Nanci Nascimento e Neide, pelo suporte e ajuda, abrindo as portas do biotério do Ipen.

Aos Profs. Nilson Dias Vieira Jr. e Gesse Eduardo Calvo Nogueira, pelo incentivo.

À Profa. Sonia Licia Baldochi, pelo uso do microscópio.

Ao pessoal da CPG do Ipen, Fernando, Ana, Vera e llze, e do CLA, Elsa e Tito, pelas constantes informações.

Ao IPEN/CNEN-SP e ICB-USP, por toda infra-estrutura utilizada na elaboração deste trabalho.

À DMC, pelo aparelho cedido a este trabalho.

À CAPES, pela bolsa de estudo concedida.

À FAPESP, pelo auxilio pesquisa (processo 05/01756-5) 


\section{ESTUDO DOS EFEITOS DA TERAPIA FOTODINÂMICA EM PERIODONTITE \\ INDUZIDA EM RATOS}

\section{Aécio Massayoshi Yamada Junior}

\section{RESUMO}

O objetivo deste trabalho foi observar a ação da terapia fotodinâmica (PDT) antimicrobiana do azul de metileno (AM) frente ao Aggregatibacter actinomycetemcomitans em estudo in vitro e em periodontite induzida em ratos. No estudo in vitro foram utilizadas suspensões de cultura de A. Actinomycetemcomitans selvagens na avaliação de diferentes parâmetros de irradiação na busca de otimizar a redução bacteriana. No estudo in vivo foram selecionados 20 ratos Wistar machos, adultos, com massa corpórea semelhante de aproximadamente $300 \mathrm{~g}$. Os animais foram submetidos a uma antibioticoterapia durante cinco dias. A indução foi elaborada através da colocação de ligaduras embebidas em $A$. actinomycetemcomitans por um periodo de 15 dias. Após este periodo, observou-se clinicamente e por sondagem a presença da doença sendo os animais divididos em dois grupos: Grupo RM $(n=10)$ - remoção mecânica de placa e Grupo RM + PDT $(n=10)$ - remoção mecânica de placa + terapia fotodinâmica. Para a PDT, o azul de metileno a 0,01\% foi aplicado topicamente diretamente nas bolsas periodontais que foram então irradiadas com um laser de emissão vermelha, $\lambda=660 \mathrm{~nm}, \mathrm{P}=100 \mathrm{~mW}, \mathrm{t}=54 \mathrm{~s}$ e $\mathrm{E}=5,4 \mathrm{~J}$. Foram realizadas coletas microbiológicas antes, imediatamente após tratamento, 3 dias e sete dias para análises por cultura e reação de polimerase em cadeia (PCR). Os resultados microbiológicos obtidos no experimento in vitro apresentaram uma eficácia da terapia fotodinâmica frente ao $A$. actinomycetemcomitans, $98,4 \%$ quando irradiado com uma energia de $5,4 \mathrm{~J}$ e $99,9 \%$ com energia de $9 \mathrm{~J}$. No estudo in vivo, foi obtida uma redução microbiana de $93,5 \%$ no grupo RM+PDT, frente a uma redução de $87,7 \%$ no grupo RM. No controle do dia 7 foi observado uma recolonização em ambos os grupos. As análises por PCR confirmaram a presença do microorganismo em todas as coletas. Estes estudos sugerem que a terapia fotodinâmica pode ser uma alternativa promissora para sua utilização coadjuvante em periodontia. 


\title{
STUDY OF THE EFFECTS OF PHOTODYNAMIC THERAPY ON INDUCED-PERIODONTITIS IN RATS
}

\author{
Aécio Massayoshi Yamada Junior
}

\begin{abstract}
The aim of this study was to evaluate the antimicrobial effects of photodynamic action of methylene blue (MB) against the Aggregatibacter actinomycetemcomitans in vitro and on periodontitis-induced in rats. The in vitro study used suspensions of $A$. actinomycetemcomitans to evaluate the different irradiation parameters to optimize the bacterial reduction. Twenty four male adult rats, body mass of $300 \mathrm{~g}$ were selected for in vivo study. The animals were submitted to an antibiotic therapy during five days. The periodontitis induction was performed by the ligature insertion imbibed in $A$. actinomycetemcomitans for 15 days. After this period, the disease was confirmed by clinical and probing aspects. The animals were divided into two groups: Group MR $(n=10)$ - mechanical plaque removal and Group MR+PDT $(n=10)$ - mechanical plaque removal + photodynamic therapy. The MB solution $0.01 \%(\mathrm{~m} / \mathrm{w})$ was topically applied into the periodontal pockets which were irradiated by a laser in red emission, $\lambda=660 \mathrm{~nm}, P=$ $100 \mathrm{~mW}, t=54 \mathrm{~s}$ e $E=5.4 \mathrm{~J}$. Microbiological samples were collected before, immediately after treatment, 3 and 7 days to cultural and Polymerase Chain Reaction (PCR) analysis. The results of in vitro study showed an antimicrobial efficacy of PDT against $A$. actinomycetemcomitans: reduction of $98.4 \%$ when the samples were irradiated with $5.4 \mathrm{~J}$ and $99.9 \%$, with $9 \mathrm{~J}$. The in vivo results showed reduction of $93.5 \%$ for Group MR+PDT and $87.7 \%$ for Group MR. The analysis on day 7 showed a recolonization in both groups. The PCR analysis confirmed the presence of the microorganism in all samples. This study suggests that the photodymnamic therapy could be a promising adjunctive therapy to periodontal treatment.
\end{abstract}




\section{SUMÁRIO}

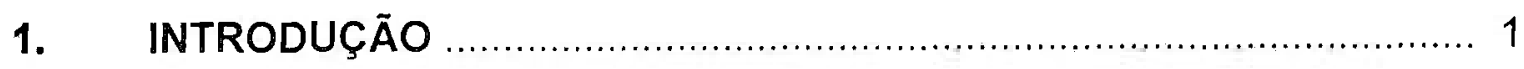

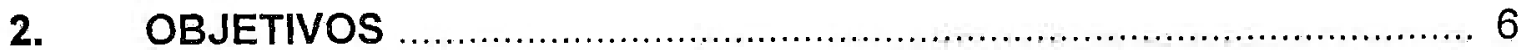

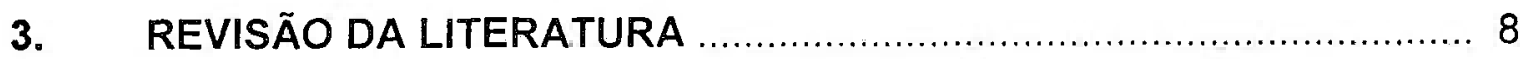

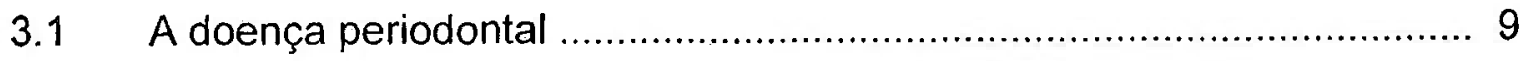

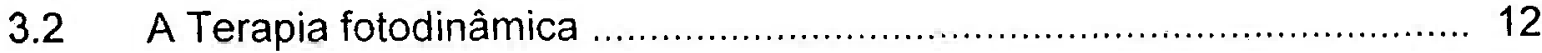

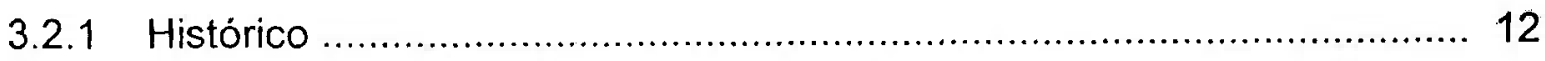

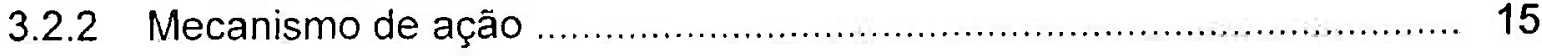

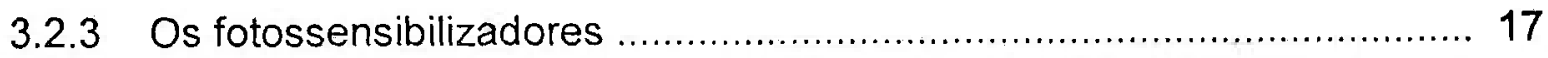

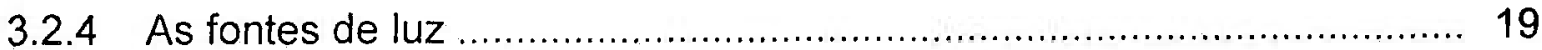

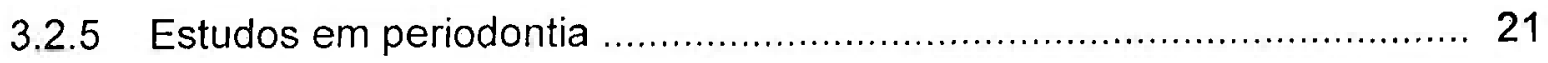

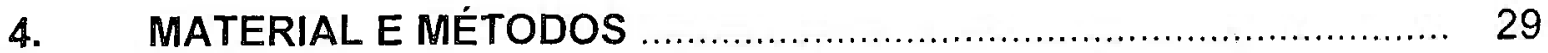

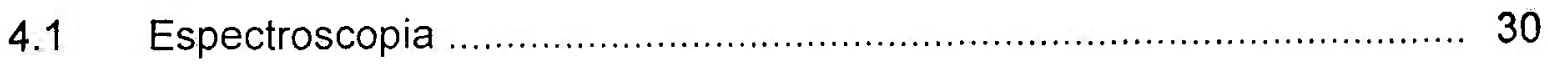

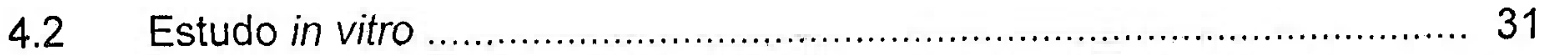

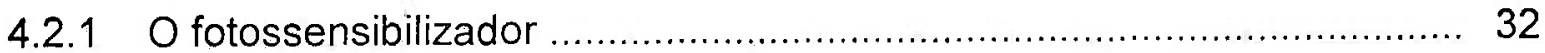

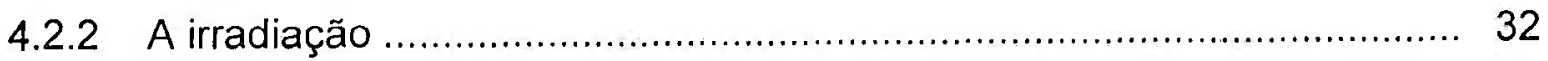

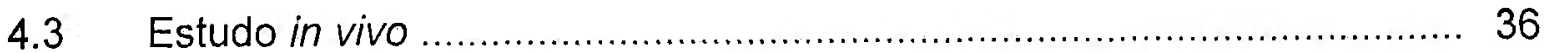

4.3.1 Aprovação do Comitê de Ética em Pesquisa .................................... 36

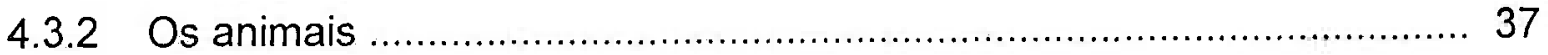

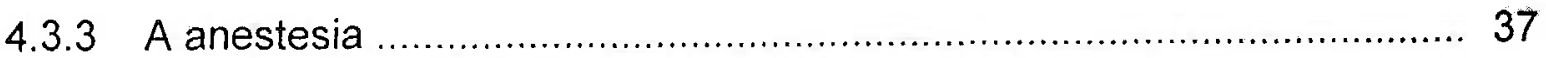

4.3.4 Indução da doença periodontal .................................................. 38

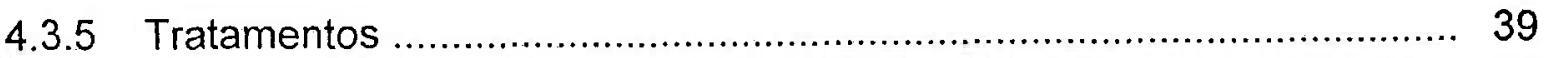

4.3.6 Coletas microbiológicas ........................................................... 41 
4.3.7 Análise da microbiota por cultura .................................................. 43

4.3.8 Análise da microbiota por reação de polimerase em cadeia (PCR) ....... 44

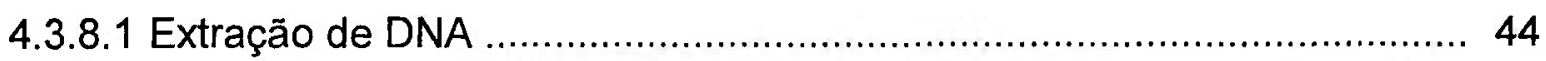

4.3.8.2 Amplificação da região 16SrRNA do A. Actinomycetemcomitans por PCR ...... 45

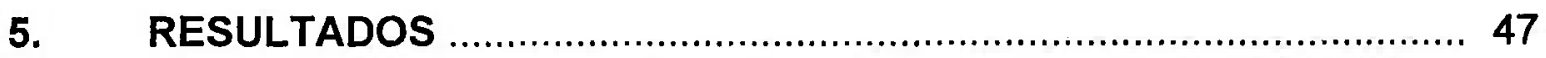

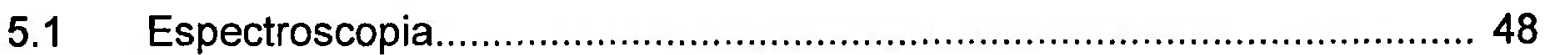

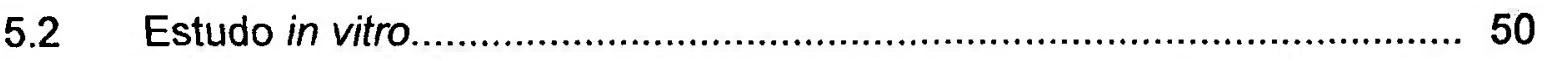

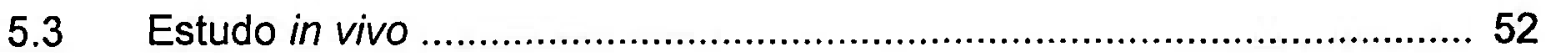

5.3.1 Análise da microbiota por cultura .................................................. 52

5.3.2 Análise da microbiota por reação de polimerase em cadeia (PCR)........ 56

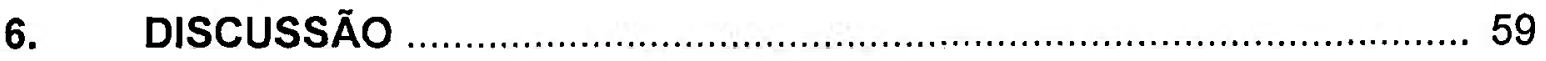

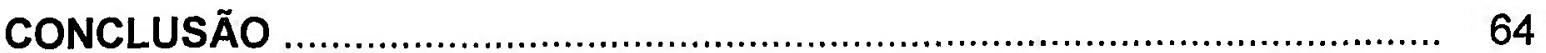

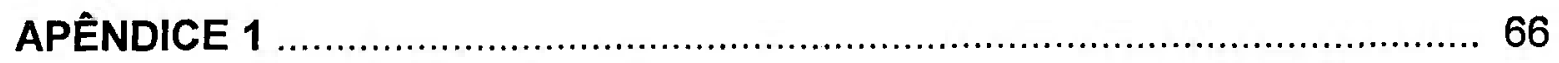

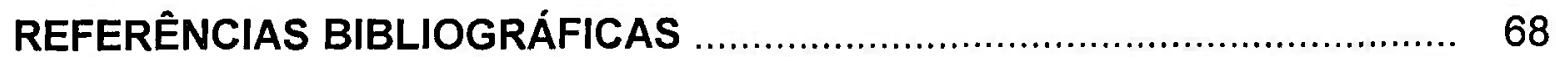


4.3.7 Análise da microbiota por cultura .................................................. 43

4.3.8 Análise da microbiota por reação de polimerase em cadeia (PCR) ....... 44

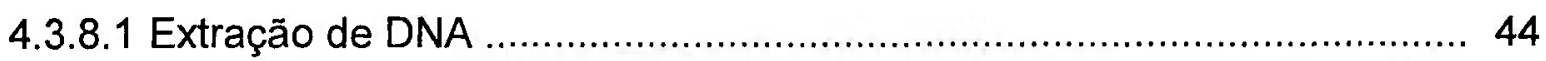

4.3.8.2 Amplificação da região 16SrRNA do A. Actinomycetemcomitans por PCR ...... 45

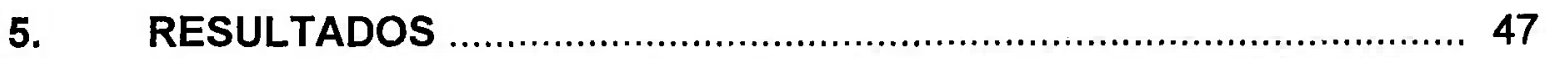

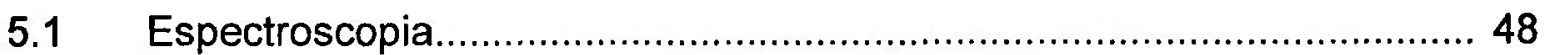

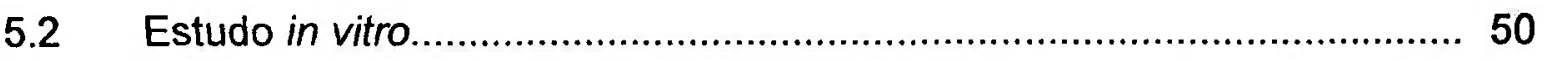

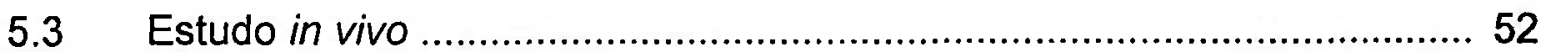

5.3.1 Análise da microbiota por cultura .................................................. 52

5.3.2 Análise da microbiota por reação de polimerase em cadeia (PCR)........ 56

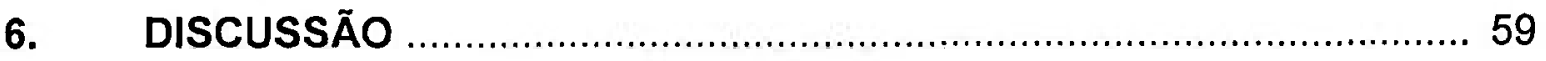

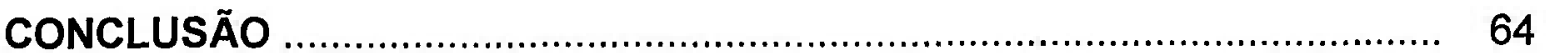

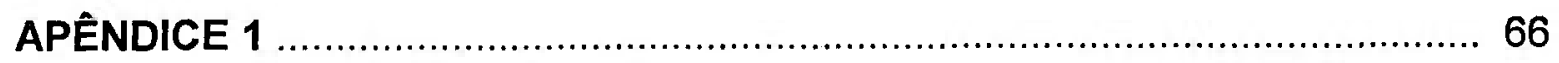

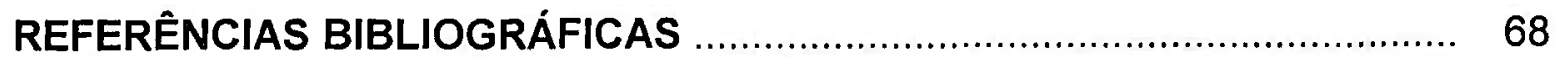


$\mathrm{AM}$ - azul de metileno

AOT - azul de orto-toluidina

$\%$ - porcentagem

$\mu \mathrm{L}-$ microlitro

$\mu \mathrm{g} / \mathrm{mL}$ - micrograma por mililitro

$\mathrm{mg} / \mathrm{mL}$ - miligrama por mililitro

${ }^{\circ} \mathrm{C}$ - grau centigrado

$\mathrm{cm}^{2}$ - centímetro quadrado

$\mathrm{CO}_{2}$ - dióxido de carbono

$\mathrm{DE}$ - densidade de energia

DP - densidade de potência

$E$ - energia

EDTA - ácido etileno diamino tetracético

FS - fotossensibilizador

h - hora

He-Ne - hélio-neônio

ICB - Instituto de Ciências Biomédicas

$J$ - joule

LEDs - light emitting diodes - diodos emissores de luz

L- - laser ausente

L+ - laser presente

min - minuto

$\mathrm{mL}-$ mililitro 
mW - miliwatt

$\mathrm{nm}$ - nanometro

$P$ - potência

PDT - photodynamic therapy

PBS - phosphate saline buffer - solução tamponada de fosfato

PCR - polymerase chain reaction - reação de polimerase em cadeia

RM - remoção mecânica

s- segundos

SPF - specific pathogen free - livre de patógenos especificos

t- tempo

$\lambda$ - comprimento de onda

TSA - ágar soja triptcaseina

TE - tris EDTA

ufc - unidades formadoraș de colônia

USP - Universidade de São Paulo

VM - verde malaquita

VMGA III - viable medium of Goteborg anaerobic

W - watt 
INTRODUÇÃO 


\section{INTRODUÇÃO}

Muitas infecções estão associadas com a presença de microorganismos na superfície dos tecidos, especialmente as da cavidade oral.

A doença periodontal é uma infecção local, de repercussão sistêmica, que afeta os tecidos periodontais tais como a gengiva, 0 cemento, o ligamento periodontal e o osso de suporte. Trata-se de uma infecção local e relativamente superficial, causada por uma microbiota específica organizada em biofilme na superfície do elemento dental. Este fato pode acarretar a destruição do osso alveolar e, se não tratada, na perda do elemento dental. A periodontite é caracterizada por periodos agudos da destruição dos tecidos periodontais, alternando com períodos crônicos da doença. Lesões periodontais são caracterizadas por inflamação da gengiva, migração apical do epitélio juncional e exposição radicular, resultando na formação de bolsa periodontal. Formas avançadas da periodontite envolvem extensas perdas do tecido conjuntivo de suporte. A transição da saúde para a progressão da doença periodontal é caracterizada por uma mudança da microbiota subgengival, com uma progressão de uma microbiota Gram-positiva para uma microbiota patogênica Gram-negativa. Portanto, o tratamento da periodontite 
consiste no controle do biofilme subgengival, raspando e aplainando a superfície radicular das bolsas periodontais, debridamento do tecido de granulação e remoção dos fatores adicionais de retenção de biofilme $e^{1}$. A reavaliação ajuda a verificar a eficiência do tratamento proposto, ou seja, se ocorreu a completa remissão desta bolsa periodontal, ou se haverá necessidade de uma intervenção cirúrgica ${ }^{2}$.

$\mathrm{Na}$ microbiota da periodontite, microorganismos como $\circ \mathrm{A}$. actinomycetemcomitans estão presentes e possuem um papel importante no seu desenvolvimento ${ }^{3}$. O A. actinomycetemcomitans sintetiza uma leucotoxina que destrói neutrófilos e monócitos e uma substância que inativa as células $T$ supressoras. Os dois fatores podem prejudicar a defesa antibacteriana gengival. Além disso, produz fatores que reduzem a proliferação de fibroblastos e células endoteliais e epiteliais, afetando assim a capacidade de resposta do periodonto à irritação'

Quando a raspagem e aplainamento da superfície dental não solucionam o processo inflamatório, o uso de terapia antibiótica é também considerada. Em recente estudo clínico, Haffajee e colaboradores administraram, coadjuvante ao tratamento periodontal, a azitromicina, o metronidazol e a doxiciclina ${ }^{4}$. Entretanto, o uso de 
tais agentes por um longo período de tempo pode selecionar microrganismos resistentes ${ }^{5}$.

Nas áreas da saúde, lasers em baixa intensidade vêm sendo utilizados com propósitos de não provocarem aumento de temperatura e, quando associados a fotossensibilizadores podem produzir morte microbiana. Este processo é conhecido por Terapia Fotodinâmica ou PDT (Photodynamic Therapy) $)^{6,7,8}$.

A PDT consiste na associação de um fotossensibilizador, normalmente exógeno, e uma fonte de luz, com o objetivo de provocar morte celular. O mecanismo de ação se dá quando o fotossensibilizador absorve os fótons de uma fonte de luz com comprimento de onda ressonante à banda de absorção e seus elétrons passam a um estado excitado. Na presença de um substrato, como por exemplo, o oxigênio, o fotossensibilizador ao retornar ao estado fundamental transfere a energia ao substrato, formando espécies de vida curta e altamente reativas, como o oxigênio singleto, que podem provocar sérios danos a microorganismos, via oxidação irreversível de componentes celulares. Vários autores relatam danos à membrana celular, às mitocôndrias e ao núcleo celular ${ }^{9,10,11}$. 
Particularmente na periodontia, a PDT pode ser indicada como coadjuvante terapêutico, otimizando o procedimento terapêutico convencional ${ }^{7,49}$.

Relatos de estudos in vitro apresentam a eficácia desta fototerapia frente ao $A$. actinomycetemcomitans ${ }^{12,13}$, porém, não com tanta facilidade na redução microbiana deste microorganismo como ocorre com os demais patógenos periodontais. Utilizando diferentes parâmetros de irradiação, procura-se otimizar a ação fototerápica do azul de metileno a 0,01\% frente a este patógeno em experimentos in vitro e in vivo.

No melhor do nosso conhecimento, a literatura ainda está carente de estudos da ação da PDT em $A$. actinomycetemcomitans "in vivo". Além disso, os poucos trabalhos relatam o uso de diferentes fotossensibilizadores, assim como os parâmetros de irradiação empregados ${ }^{12,13}$.

Portanto, neste trabalho foi feito um estudo "in vitro" para investigação dos parâmetros de irradiação e uma avaliação "in vivo" da ação da terapia fotodinâmica antimicrobiana frente ao $A$. actinomycetemcomitans em periodontite induzida em ratos. 
OBJETIVOS 


\section{OBJETIVOS}

- Analisar por espectroscopia de absorção óptica o comportamento do azul de metileno na presença do $A$. actinomycetemcomitans;

- Avaliar, in vitro, por análise microbiológica, o efeito da terapia fotodinâmica na redução de A. actinomycetemcomitans, associando luz de emissão vermelha e azul de metileno em duas condições de irradiação;

- Desenvolver uma metodologia de indução de periodontite agressiva em ratos caracterizada pela presença de $A$. actinomycetemcomitans;

- Investigar, in vivo, os efeitos da terapia fotodinâmica como coadjuvante ao tratamento usual de periodontite por remoção mecânica de biofilme, comparando, por análise microbiológica, a redução de $A$. actinomycetemcomitans. 
REVISÃO DE LITERATURA 


\section{REVISÃO DE LITERATURA}

\subsection{A doença periodontal}

A periodontite é uma doença multifatorial, tendo como iniciador a presença de um biofilme bacteriano específico ${ }^{14}$. Este biofilme é composto de uma grande variedade de espécimes microbianos e proteínas que se aderem à superfície dental. Em gengivas saudáveis, organismos Gram-positivos como o Actinomyces e os Streptococcus dominam a microbiota deste biofilme bacteriano. Este por sua vez, permanecendo por um longo período aderido à estrutura dental, biofilme bacteriano maduro, sofrerá uma mudança da sua flora microbiana, passando a predominar os anaeróbios Gram-negativos. Alguns dos microorganismos mais comuns associados a doença periodontal são as Porphyromonas gingivalis, Prevotella intermedia, $T$. forsythus e o A. actinomycetemcomitans ${ }^{15}$.

O biofilme induzirá a periodontite, provocando uma inflamação gengival e, em alguns sítios, a migração apical do epitélio acompanhada de perda de tecido conjuntivo e osso alveolar, ocasionando a formação das bolsas periodontais ${ }^{16}$. 
A doença periodontal pode ser classificada em 7 grandes categorias frente ao seu poder destrutivo ${ }^{17}$ :

- Periodontite crônica;

- Periodontite localizada agressiva;

- Periodontite generalizada agressiva;

- Periodontite devido a uma doença sistêmica;

- Periodontite / Gengivite ulcerativa necrosante;

- Abcessos periodontais;

- Lesões endo-perio.

A maioria dos pacientes com periodontite irá desenvolver a forma crônica ${ }^{18}$. O paciente típico possui mais de 30 anos com substancial acúmulo de placa e cálculo dental associado com a presença de inflamação gengival, bolsas periodontais e perda de inserção. Na maioria dos casos, a progressão da doença é lenta, porém curtos periodos de rápidas perdas de inserção podem ocorrer $^{19}$.

A periodontite agressiva é menos comum e afeta principalmente pacientes jovens, abaixo dos 30 anos. Esta doença pode ocorrer de forma generalizada ou localizada, tendo como característica principal a extensa destruição dos tecidos periodontais em curtos espaços de tempo ${ }^{20}$. Geralmente está relacionada com uma microbiota específica, 
tendo como um dos principais patógenos $\circ A$. actinomycetemcomitans ${ }^{21}$.

Recente estudo realizado por Schacher et $a l^{22}$, comparando a microbiota subgengival em 60 pacientes com periodontite crônica e/ou agressiva, demonstraram a presença em grande quantidade, assim como a freqüência do $A$. actinomycetemcomitans, em pacientes com periodontite agressiva em relação aos crônicos.

Relatos do $A$. actinomycetemcomitans como agente causador de inúmeras infecções bacterianas como endocardites, septicemias, abcessos e osteomielites, vem sendo reportados desde a década de $60^{23,21}$

A colonização deste microorganismo ocorre não somente na superfície dental, mas como também sobre colônias bacterianas já presentes no biofilme, assim como no tecido epitelial. Além disto, esta bactéria produz uma leucotoxina capaz de provocar a lise de neutrófilos, monócitos e uma sub-população de linfócitos ${ }^{21}$.

O procedimento de raspagem e alisamento radicular é o tratamento usual nestes casos de periodontite, seja ela crônica ou agressiva. Porém, quando não se obtém uma resposta clínica favorável, opta-se por uma terapêutica antibiótica ou ainda uma intervenção cirúrgica. Recentemente, López et al. ${ }^{24}$ relataram a 
necessidade da utilização de dois antibióticos concomitantemente, metronidazol + amoxicilina, para uma efetiva resposta clínica do paciente, assim como uma grande redução microbiana analisada por hibridação DNA-DNA.

Em revisão elaborada por Umeda e col. $^{25}$, citam-se vários estudos utilizando tetraciclina na supressão de patógenos periodontais. No entanto, a utilização deste antibiótico juntamente com a raspagem e alisamento radicular leva a um pequeno aumento na redução destes microorganismos, quando comparado somente com a terapêutica de eliminação mecânica.

\subsection{A Terapia Fotodinâmica}

\subsubsection{Histórico}

Os primeiros relatos da terapia fotodinâmica ocorreram no início do século passado com os experimentos de Raab (1900), no qual é descrito a ação letal do corante acridina juntamente com a luz de relâmpagos sobre paramécios. Ele postulou que este efeito era causado pela transferência da energia da luz para a substância 
química, fato semelhante ao que ocorre no processo de fotossintese. A utilização da luz juntamente com o corante foi altamente citotóxica.

Em 1903, Tappeiner utilizou a aplicação tópica do corante eosina e exposição à luz para o tratamento de um câncer de pele. Em 1913, Meyer-Betz fez uma auto-injeção de $200 \mathrm{mg}$ do que ele acreditava ser hematoporfirina pura e não sentiu nenhum efeito, porém ao se expor à luz, teve fotossensibilidade na pele por vários meses.

Policard, em 1925, estudou porfirinas objetivando a produção de efeitos fototóxicos em tecidos, principalmente em tumores malignos. A história da chamada primeira geração de drogas para a terapia fotodinâmica, à base de derivados hematoporfirínicos, começou com Schwartz no início da década de 50. Ele mostrou que nos experimentos de Meyer-Betz, o princípio ativo não era a hematoporfirina, pois esse composto é facilmente eliminado do organismo, mas na realidade tratava-se de uma mistura de diversas substâncias oligoméricas provenientes do método original de sintese e isolamento da mesma. Schwartz enriqueceu a mistura de oligômeros (chamou o preparado de hematoporfirina D) e Lipson, sob orientação de Schwartz na década de 60, investigou o acúmulo preferencial deles em tumores, implantados em camundongos e ratos, 
e observou que a incidência de luz proporcionava regressão da doença.

$\mathrm{Na}$ década de 60, Lipson investigou o acúmulo preferencial da hematoporfirina em tumores, implantados em camundongos e ratos e observou que a incidência de luz proporcionava regressão da doença. Como resultado desses estudos, no final daquela década, Lipson obteve sucesso no tratamento de uma mulher portadora de câncer de mama usando hematoporfirina $D$ e irradiando seletivamente o tumor, marcando assim, o início da terapia fotodinâmica como terapia clínica para câncer.

No fim da década de 80 , um dos derivados da hematoporfirina, o Photofrin $\AA$, foi $\circ$ primeiros fotossensibilizador aprovado pelo FDA (Food and Drugs Administration, Estados Unidos) para o tratamento de tumores. ${ }^{26}$

A década de 90 marcou o recomeço da utilização da terapia fotodinâmica com finalidade antimicrobiana. A PDT antimicrobiana encontra-se bem fundamentada na literatura, principalmente em casos de infecções localizadas, de pouca profundidade e microbiota conhecida. Sua ação antifúngica também está sendo estudada. ${ }^{27,28,29}$ 


\subsubsection{Mecanismo de ação}

A molécula do fotossensibilizador deve absorver um fóton de luz, saindo do seu estado fundamental $\left(S_{0}\right)$ para seu estado excitado singleto $\left(S_{1}\right)$. Neste momento, pode ocorrer perda de energia por processos de fluorescência $(F)$ do estado $S_{1}$ para $S_{0}$ e/ou ocorrer cruzamento intersistemas (CIS), levando a molécula para o estado excitado tripleto $\left(T_{1}\right)$. A energia no estado $T_{1}$ pode ser dissipada pelo processo de fosforescência (Fs), devolvendo a molécula para o estado $S_{0}$ e/ou transferir a energia para outras moléculas no meio ${ }^{6}$ (Figura 1).

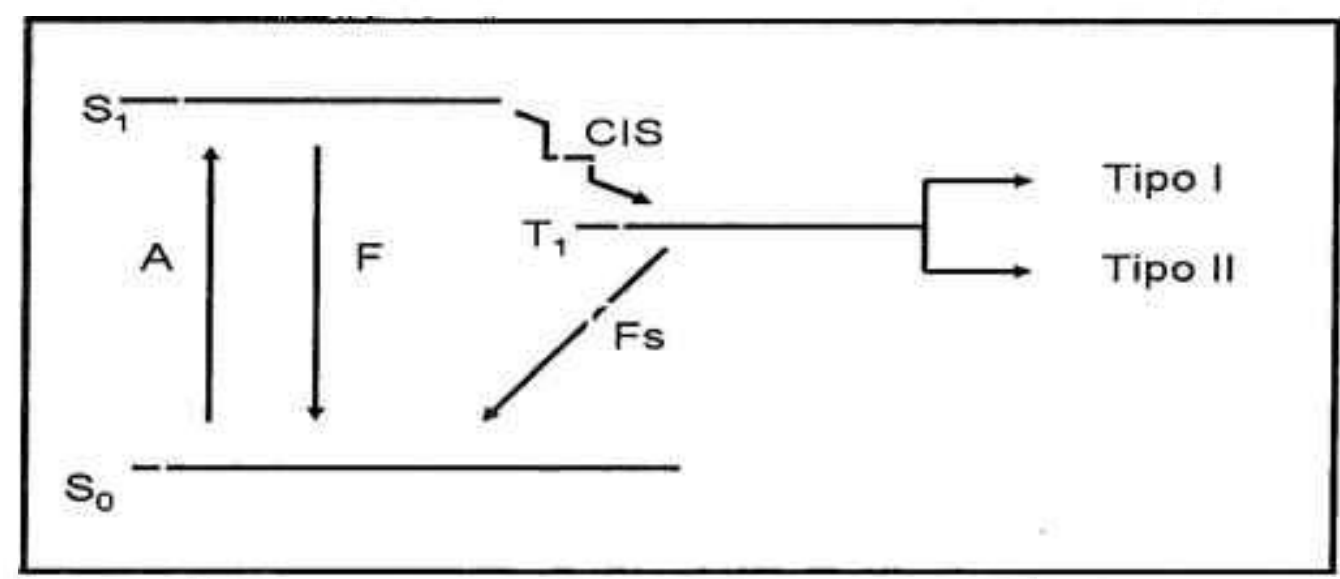

Figura 1 - Diagrama de Jablonski. Representação esquemática do sistema de trocas de energia na molécula do fotossensibilizador 
$\mathrm{Na}$ reação do tipo I, ocorre a transferência de energia do fotossensibilizador excitado ao substrato, ocorrendo reações do óxidoredução com biomoléculas e produção das espécies reativas de oxigênio, como superóxido, radical hidroxila, etc. Na reação do tipo II, a molécula do fotossensibilizador encontra com uma molécula de oxigênio e transfere sua energia para esta molécula formando o estado excitado singleto do oxigênio. Este estado do oxigênio é quimicamente muito ativo e pode induzir várias reações em cadeia com componentes da célula, tais como DNA, proteínas, fosfolipídios da membrana celular, etc., tendo como resultado a morte da célula ${ }^{7}$. Por outro lado, a molécula de oxigênio no estado singleto pode perder sua energia por processos de emissão de fótons ou cruzamento intersistemas e voltar para seu estado fundamental sem começar qualquer reação. Então, a eficiência do processo fotodinâmico aumenta quando o rendimento quântico e o tempo de vida do estado tripleto do fotossensibilizador aumentam, bem como com o tempo de vida do estado singleto do oxigênio.

Para aumentar a eficiência do processo também pode ser aumentada a velocidade de reação do oxigênio singleto com certos reagentes, tais como DNA, proteínas ou membranas celulares. Isto acontece quando o oxigênio singleto é gerado perto deste reagente, 0 
que significa aumentar a probabilidade de encontro entre este reagente e o oxigênio singleto. Um caso especial é quando o sensibilizador que fornece sua energia para oxigênio já está ligado com este reagente. Portanto, mais um caminho para aumentar a eficiência do processo fotodinâmico é aumentar a afinidade do sensibilizador com as estruturas que devem ser destruídas ${ }^{8}$.

\subsubsection{Os fotossensibilizadores}

A essência da PDT provém da utilização de um fotossensibilizador com banda de absorção ressonante com 0 comprimento de onda de uma fonte de luz, objetivando provocar a necrose celular ou morte microbiana. Para Wainwright ${ }^{30} \circ$ agente fotossensibilizador ideal deve apresentar como características: estabilidade biológica, eficiência fotoquimica, seletividade pela célula alvo e mínimo efeito tóxico às células normais. Dentre os fotossensibilizadores, os mais utilizados na terapia fotodinâmica antimicrobiana são: as porfirinas, as ftalocianinas, as fenotiazinas, as cianinas, as acridinas, os corantes fitoterápicos e as clorinas.

A maioria dos fotossensibilizadores que vem sendo estudados 
para o tratamento do câncer e outras doenças teciduais estão baseadas nas porfirinas, clorinas, bacterioclorinas $e$ nas ftalocianinas $^{31}$. No entanto, corantes que são frequentemente propostos como fotossensibilizadores antimicrobianos possuem diferentes estruturas moleculares, como o rosa bengala $(R B)^{32}$ e as fenotiazinas $\mathrm{AOT}^{33}$ e $\mathrm{AM}^{34}$.

Sabe-se que as bactérias Gram positivas são muito mais sensiveis à ação fotodinâmica em relação as Gram negativas e que o fotossensibilizador ideal para exterminar bacteria deve ser catiônico. ${ }^{35}$

As fenotiazinas são compostos heteroaromáticos tricíclicos que em baixas concentrações não produzem ação citotóxica e nem danos a células, como queratinócitos e fibroblastos ${ }^{11}$. Segundo Wainwright ${ }^{36}$ estes corantes possuem a capacidade de se ligarem a membrana celular e a componentes do DNA. Há um crescente número de estudos evidenciando a eficácia fotodinâmica deste sal frente a microorganismos como, Escherichia coli e Staphylococcus aureus ${ }^{37}$, Enterococcus faecalis ${ }^{29}$, diversas bactérias periodontais ${ }^{38}$ e fungos como a Candida ${ }^{39}$.

O AM é um corante catiônico bem estabelecido como fotossensibilizador (FS) na terapia fotodinâmica, já que sua banda de absorção se situa entre $620 \mathrm{~nm}-670 \mathrm{~nm}$. Recente trabalho 
investigou as propriedades de ligação do MB ao DNA de esperma de arenque por métodos espectroscópicos ${ }^{40}$. Os autores sugerem que o azul de metileno sofre fotodegradação na presença do DNA, resultando na formação de espécies reativas de oxigênio, que contribuem para a fotooxidação auto-sensibilizada do corante.

Os fotossensibilizadores mais utilizados clinicamente em tratamentos antimicrobianos são os sais de fenotiazinas. O AM e o AOT, juntamente com as fontes de luz de emissão vermelha, estão sendo utilizados na desinfecção de produtos sanguíneos e na desinfeç̧ão de cavidades dentais, assim como estão sendo propostos no tratamento de periodontite ${ }^{35,38,49}$.

\subsubsection{As fontes de luz}

Os fatores determinantes de uma fototerapia eficaz são: um alto coeficiente de absorção do corante, a concentração deste fotossensibilizador e a taxa de energia da fonte de luz. Em princípio todos os tipos de lâmpadas podem ser utilizados. O espectro de emissão da luz branca converge na banda de absorção da maioria dos corantes ${ }^{41}$. 
As primeiras fontes de luz utilizadas em terapia fotodinâmica foram lâmpadas convencionais, com luz não coerente e policromática, com um forte componente térmico associado. Com o advento dos lasers, este passou a substituir as demais fontes de luz por serem monocromáticos e com isso poderem ser associados a fotossensibilizadores com banda de absorção ressonante ao comprimento de onda do laser, ou seja, capazes de absorver a maior parte da irradiação emitida pela fonte de luz. Assim, a densidade de energia é facilmente calculada e a área de irradiação pode ser bem controlada, focalizando o tratamento ${ }^{26}$.

A emissão de luz advinda de um laser pode ter os mais variados comprimentos de onda (argônio, He-Ne, de corantes, de vapores de metais e diodo), no entanto, os lasers de diodo de emissão em $\lambda=660 \mathrm{~nm}$ são os mais utilizados. São equipamentos com potência suficiente para a terapia fotodinâmica, compactos, robustos, com sistemas ópticos relativamente simples, custo mais acessivel, além de possuírem um comprimento de onda ressonante a banda de absorção da maioria dos corantes atualmente utilizados ${ }^{42}$.

A mais recente alternativa são os LEDs (light emitting diodes diodos emissores de luz), que também podem ser utilizados com sucesso como fonte de luz em terapia fotodinâmica, principalmente no 
tratamento de melanomas, pois têm baixo custo, apresentam um baixo componente térmico e luz monocromática, com largura de banda da ordem de $40 \mathrm{~nm}$. Entretanto, o acoplamento em fibras ainda apresenta desvantagens quando comparados aos lasers ${ }^{42}$.

\subsubsection{Estudos em periodontia}

O potencial da terapia fotodinâmica em bactérias orais começou a ser investigado na década de 90 quando Dobson \& Wilson ${ }^{43}$ analisaram a redução bacteriana de $S$. sanguis, $A$. actinomycetemcomitans, $F$. nucleatum e $P$. gingivalis. Foram utilizadas bactérias do biofilme subgengival de pacientes com periodontite crônica. Amostras da placa subgengival foram expostas ao laser de He-Ne $(P=7,3 m W)$ na presença e na ausência de diferentes corantes. Os autores concluíram que os corantes AM e AOT foram eficazes na redução das quatro espécies bacterianas. No entanto, os corantes, ftalocianina dissulfonada de alumínio, hematoporfirina e éster de hematoporfirina, sensibilizaram apenas alguns dos microorganismos. Os autores sugerem que a terapia fotodinâmica pode ser efetiva em eliminar bactérias 
periodontopatogênicas da placa bacteriana.

Ainda em 1992, Wilson e col. ${ }^{44}$, investigando vinte e sete outros compostos associados a um laser de $\mathrm{He}-\mathrm{Ne}$ de $7,5 \mathrm{~mW}$ frente a diferentes microorganismos, observaram que apenas os corantes AM, AOT e o cloreto azul B, na concentração de $0,005 \%$, foram efetivos contra as bactérias $S$. sanguis, $A$. actinomycetemcomitans, $F$. nucleatum e $P$. gingivalis, quando associados a uma exposição de 30 s.

Seguindo a mesma linha de pesquisa, Wilson e col. $^{45}$ demonstraram bons resultados de redução bacteriana utilizando o laser de He-Ne (Hélio-Neônio), $\lambda=632,8$ nm e 7,3mW de potência, associado aos fotossensibilizadores AOT, AM, ftalocianina e hematoporfirinas. Foram testadas as bactérias $S$. sanguis, $A$. actinomycetemcomitans, $F$. nucleatum e $P$. gingivalis. Foram utilizadas bactérias do biofilme subgengival de pacientes com periodontite crônica. Amostras da placa subgengival foram expostas à luz, na presença e na ausência do corante azul de toluidina na concentração de $50 \mu \mathrm{g} / \mathrm{mL}$. Os autores concluíram que a combinação laser e corante alcançou uma significante redução bacteriana, sendo que a média de redução foi de $91,1 \%$ nas bactérias aeróbias, $96,9 \%$ nas anaeróbias, $100 \%$ nas pigmentadas anaeróbias e $94,4 \%$ para os 
Streptococcus. Entretanto, a redução bacteriana não foi significante na presença apenas do corante ou apenas do laser. Isto sugere que $o$ laser em baixa intensidade associado ao corante apropriado pode ser efetivo como tratamento coadjuvante ao debridamento mecânico em inflamações periodontais, pois três dos principais responsáveis pela etiologia da doença periodontal podem ser mortos por esta modalidade de tratamento.

Já em 1995, Wilson. et al. ${ }^{10}$ realizaram estudo em placas bacterianas obtidas de dez voluntários. Foram utilizados como corantes o AOT e a ftalocianina dissulfonada de alumínio, combinados com a irradiação de um laser de He-Ne e um laser de AsGaAl respectivamente. Os resultados mostraram uma grande redução das bactérias anaeróbias assim como dos Streptococcus e Actinomyces viáveis. A combinação do He-Ne e AOT mostrou-se mais eficiente do que a combinação AsGaAl e ftalocianina, utilizando energia de 1,31J.

Preocupados em não provocar danos a tecidos adjacentes à aplicação da terapia fotodinâmica no tratamento da doença periodontal, Soukos et al. ${ }^{11}$ avaliaram o efeito fotodinâmico da irradiação de um laser com emissão vermelha e do corante AOT sobre queratinócitos orais humanos, fibroblastos e $S$. Sanguis. Os autores concluíram que o uso de baixas concentrações de corante e 
da irradiação provocava a morte bacteriana e não reduzia a viabilidade celular.

König e col. ${ }^{46}$, analisaram a terapia fotodinâmica com laser de He-Ne de 60mW, sem o uso de corantes externos, contra determinadas bactérias capazes de sintetizar a protoporfirina IX. As bactérias utilizadas neste estudo foram: Propionibacterium acnes, Actinomyces odontlyticus, $P$. gingivalis, $P$. intermédia e $S$. mutans (como controle). Os resultados mostraram uma redução bacteriana de até $50 \%$ em algumas espécies produtoras de endoporfirinas, pronunciando efeito sobre a bactéria pigmentada e nenhum efeito sobre o S. mutans, incapaz de produzir porfirinas endógenas e nem apresenta pigmentação. Baseados nos resultados, os autores preconizam esta técnica como método terapêutico contra bactérias produtoras de endoporfirinas. Ainda ressaltam que o aumento da resistência bacteriana aos antibióticos torna cada vez mais importante a busca de novas formas de tratamento a infecções; a terapia fotodinâmica se mostrou uma interessante alternativa.

A descontaminação da superfície de implantes no tratamento da periimplantite foi o estudo de Dörtbudak e colaboladores ${ }^{9}$. Foi realizada uma pesquisa, in vivo, em 15 pacientes, utilizando-se um laser de diodo $(\lambda=690 \mathrm{~m})$ associado ao corante AOT a $0,1 \%$. Coletas 
microbiológicas foram obtidas antes e após o tratamento para a quantificação das bactérias: $P$. gingivalis, $P$. intermedia e $A$. actinomycetemcomitans. Os autores concluiram que a associação do corante com o laser resultou em significativa redução bacteriana nas três espécies pesquisadas, sendo que em nenhuma delas houve total eliminação da cultura bacteriana.

Associando o corante AOT $(1 \mathrm{mg} / \mathrm{ml})$ a um laser diodo com $100 \mathrm{~mW}$ de potência e comprimento de onda $630 \mathrm{~nm}$, sobre $P$. gingivalis, inoculados em molares superiores de ratos, Komerik et al. ${ }^{47}$ não encontraram após o tratamento espécimes viáveis do microorganismo em todas as doses investigadas, além de um decréscimo de perda óssea nos grupos irradiados quando comparados ao controle não irradiado. Concluiu-se que a terapia fotodinâmica pode ser usada como procedimento alternativo no tratamento antimicrobiano em periodontia.

Matevski et al. ${ }^{48}$ mostraram que a terapia fotodinâmica também pode ser utilizada com fontes de luz convencionais. Relataram um efeito bactericida eficiente utilizando lâmpada de xenônio associado a filtros na região do vermelho. O fotossensibilizandor utilizado foi o AOT agindo sobre suspensão de $P$. gingivalis. Uma redução de aproximadamente 2,12 logs foi observada quanto se utilizou a dose de 
$2,2 \mathrm{~J} / \mathrm{cm}^{2}$ e com um aumento de dose para $5,63 \mathrm{~J} / \mathrm{cm}^{2}$, a redução foi de 3 logs.

$\mathrm{Na}$ tentativa de criar um protocolo otimizado de aplicação da terapia fotodinâmica frente a bactérias periodontopatogênicas, Chan \& Lai em $2003^{13}$, utilizaram como corante o $A M$ a $0,01 \%$ e três diferentes fontes de luz: laser de $\mathrm{He}-\mathrm{Ne}(\lambda=632,8 \mathrm{~nm}$ e $P=30 \mathrm{~mW})$, laser de diodo $(\lambda=665 \mathrm{~nm}$ e $P=100 \mathrm{~mW})$ e laser de diodo $(\lambda=830 \mathrm{~nm}$ e $\mathrm{P}=100 \mathrm{~mW}$ ). Os resultados comprovaram que o melhor efeito bactericida foi obtido com a combinação do $\mathrm{AM}$ e do laser de diodo $(\lambda=665 \mathrm{~nm}$ e $P=100 \mathrm{~mW})$ com um tempo de irradiação de $60 \mathrm{~s}$. Foi obtido uma redução de $95 \%$ de $A$. actinomycetemcomitans e $F$. Nucleatum, $99-100 \%$ das pigmentadas pretas $(P$. gingivalis e $P$. intermedia) e da $S$. sanguis. Os autores concluiram que a utilização de um laser de diodo $(\lambda=665 \mathrm{~nm}$ e $P=100 \mathrm{~mW})$ com um tempo de irradiação de 60 s pode ser uma excelente ferramenta a ser utilizada concomitantemente com o debridamento mecânico na prevenção da recolonização de lesões subgengivais por microorganismos patogênicos.

O estudo de Pfitzner et al. ${ }^{55}$ avaliaram a eficácia dos fotossensibilizadores clorina e6, BLC1010 e BLC1014, utilizados em uma concentração de $10 \mu \mathrm{M}$, juntamente com um laser de diodo de 
$662 \mathrm{~nm}$ e potência máxima de $4 \mathrm{~W}$. As amostras foram irradiadas com duas diferentes densidades de energia: $5,3 \mathrm{~J} / \mathrm{cm}^{2}$ e $20,1 \mathrm{~J} / \mathrm{cm}^{2}$. Os autores concluíram que os fotossensibilizadores clorina e6 e BLC1010 são vantajosos na supressão de bactérias periodontopatogênicas.

Uma redução de $99,9 \%$ de $A$. actinomycetemcomitans foi obtida por Prates et al..$^{12}$,em estudo in vitro, com a combinação do corante verde malaquita a $0,01 \%$ e um laser de diodo de comprimento de onda de $660 \mathrm{~nm}$, potência de $30 \mathrm{~mW}$ e tempo de irradiação de $5 \mathrm{~min}$.

Almeida e colaboradores $^{38}$ avaliaram histológica e radiograficamente os efeitos da terapia fotodinâmica na progressão da doença periodontal induzida em ratos. Foi utilizado como corante o AM $(100 \mu \mathrm{g} / \mathrm{mL})$ e irradiado com um laser $(\lambda=685 \mathrm{~nm}$ e $P=0,05 \mathrm{~W})$ por um tempo de 120s. Os exames radiográficos mostraram uma menor perda óssea no grupo PDT em comparação ao grupo controle nos dias 5 e 15. Já no dia 30 pós-tratamento não foram observadas diferenças entre os grupos. Em relação aos dados histológicos, no dia 15 foram observadas diferenças significantes na extensão da reação inflamatória do tecido gengival. Os autores concluiram que a PDT reduz a destruição dos tecidos periodontais.

Um dos primeiros estudos clínico no tratamento da periodontite agressiva utilizando-se a terapia fotodinâmica foi realizado neste ano 
(2007) por Oliveira e col. ${ }^{49}$. Compararam a efetividade da PDT frente ao tratamento usual da periodontia, ou seja, raspagem e alisamento radicular em 10 pacientes. Os resultados comprovaram que não houve diferença nas observações clínica entre os pacientes. Tanto o tratamento de raspagem e alisamento radicular quanto o de aplicação da terapia fotodinâmica foram efetivos. 
MATERIAL E MÉTODOS 


\section{4- MATERIAL E MÉTODOS}

\subsection{A espectroscopia}

O espectro de absorção óptica do AM na concentração de 0,01\% ( $\mathrm{m} / \mathrm{V})$ foi obtido em um espectrofotômetro CARY OLIS-17 Inc. (On-Line Instrument Systems, Inc. USA) utilizando-se uma cubeta de quartzo com caminho óptico de $1 \mathrm{~cm}$. A solução do corante foi depositada na cubeta para obtenção do espectro de absorção na região visível do espectro eletromagnético. $O$ equipamento incide um feixe luminoso na solução do corante, e através de um sensor, lê o resultado da absorção. O sinal luminoso residual é captado e encaminhado a um software (OLIS-17) para gerar um gráfico que apresenta o comprimento de onda $(\mathrm{nm})$ no eixo $X$ e a absorção (unidades arbitrárias- u.a.) no eixo Y.

Foram procedidas três leituras, sendo a primeira com a suspensão contendo células bacterianas, a segunda com o azul de metileno em solução sem bactérias. A terceira leitura foi realizada na suspensão bacteriana associada ao fotossensibilizador, com 
concentração final de $0,01 \%(\approx 300 \mu \mathrm{M})$ respeitando-se o tempo de préirradiação de 5 minutos. Antes de cada leitura, a suspensão de $A$. actinomycetemcomitans foi agitada para homogeneização e a temperatura na sala do espectrofotômetro foi mantida em $25^{\circ} \mathrm{C}$ durante todo o experimento.

\section{2- Estudo in vitro}

Foram utilizados $A$. actinomycetemcomitans isolados de pacientes com periodontite, obtidos do estoque do Laboratório de Microbiologia Oral do ICB/USP, espécimes cultivados em placas de Petri contendo ágar soja tripticaseína (TSA) acrescidode $5 \%$ de extrato de levedura, e incubados em condições de microaerofilia, a $37^{\circ} \mathrm{C}$, por $48 \mathrm{~h}$. Foi realizado teste de catalase, análise morfológica da colônia e teste de coloração de Gram para confirmação presuntiva da espécie.

Após $48 \mathrm{~h}$ de crescimento, as bactérias foram colhidas por meio de raspagem das placas e diluídas em $10 \mathrm{~mL}$ de solução tampão de PBS (Phosphate Buffer Saline, pH 7,2) até conseguir a turvação na 
escala 0,5 de Mc Farland, correspondente a $1,5 \times 10^{8}$ ufc's (unidades formadoras de colônias) por mililitro. Alíquotas de $900 \mu \mathrm{L}$ desta solução foram depositadas em cinco tubos de ensaio previamente identificados conforme a divisão dos grupos.

\subsection{1- O fotossensibilizador}

O fotossensibilizador utilizado neste estudo foi o azul de metileno (SIGMA - ALDRICH / M4907) em solução aquosa. As soluções foram preparadas no Laboratório do Centro de Lasers e Aplicações e armazenadas em vidro âmbar a temperatura de $5^{\circ} \mathrm{C}$.

\subsection{2- A irradiação}

Nos grupos $L+$, a irradiação laser foi feita na parte inferior do tubo, conforme mostram as Figuras 2-A e 2-B, de forma que o feixe percorresse o interior do líquido dentro do tubo de ensaio. Foi utilizado 
um laser de emissão vermelha, $\lambda=660 \mathrm{~nm}$, potência de saida igual a $30 \mathrm{~mW}$, e energias de $5,4 \mathrm{~J}$ e $9 \mathrm{~J}$, correspondendo a $180 \mathrm{~s}$ e $300 \mathrm{~s}$, respectivamente, conforme os grupos:

1.Grupo L-AM- : Controle (sem irradiação laser e sem fotossensibilizador);

2.Grupo L+AM- : somente irradiação com laser com 9J de energia;

3.Grupo L-AM+: somente corante azul de metileno por 5 minutos (tempo de pré-irradiação, isto é, tempo que o corante interage com a célula);

4.Grupo L5,4+AM+ : azul de metileno mais irradiação de 5,4J;

5.Grupo L9+AM+ : azul de metileno mais irradiação de 9J.

Aos grupos 3,4 e 5 foi adicionado um volume de $100 \mu \mathrm{L}$ de corante azul de metileno na concentração de $0,1 \%$, chegando todos estes grupos a uma concentração final de $0,01 \%(\mathrm{~m} / \mathrm{N})$. Com essa diluição, o número estimado de ufc passou de $1,5 \times 10^{8}$ para $1,35 \times 10^{8}$ tanto nos grupos $L-A M+, L 5,4+A M+, L 9+A M+$, quanto nos grupos $L-$ AM- e L+AM-, que receberam o mesmo volume de solução tampão. 


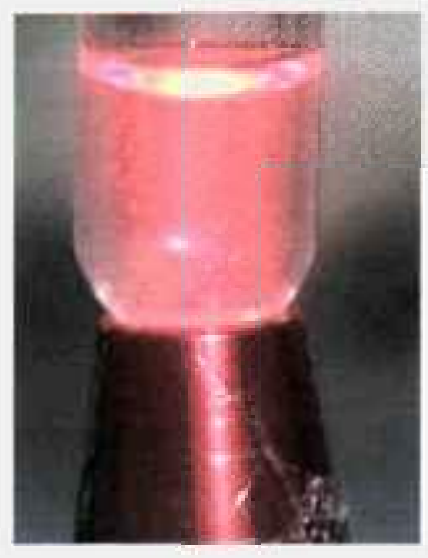

(A)

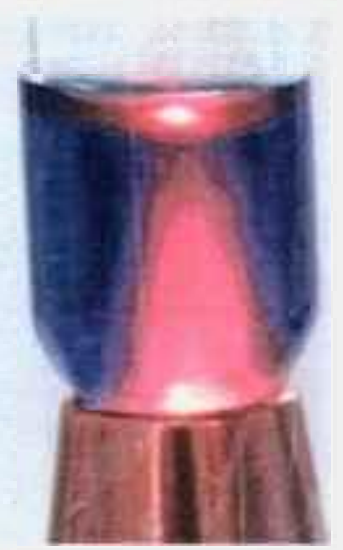

(B)

Figura 2 - (A) Irradiação na parte inferior do tubo de ensaio sem corante na solução. (B) Irradiação na parte inferior do tubo de ensaio com azul de metileno em solução, ilustrando a absorção do sistema contendo suspensão bacteriana e fotossensibilizador. 
Após realização dos procedimentos de irradiação, foi iniciado o processo de diluição seriada em uma concentração de $1,35 \times 10^{8}$ ufc/mL. Uma alíquota de $100 \mu \mathrm{L}$ foi retirada do tubo de ensaio com auxilio de uma micropipeta e depositada em um eppendorf previamente preparado e identificado, contendo um volume de $900 \mu \mathrm{L}$ de PBS. Passou-se então a uma concentração de $1,35 \times 10^{7}$ ufc/mL, de onde também foi retirado mais $100 \mu \mathrm{L}$ e adicionado a $900 \mu \mathrm{L}$ em outro eppendorf, encontrando assim a concentração $1,35 \times 10^{6}$ ufc/mL. A cada diluição, o número de ufc foi reduzido dez vezes e o processo foi repetido até a concentração de $1,35 \times 10^{5}$, de onde foi retirada mais três alíquotas de $100 \mu \mathrm{L}$ e semeadas em placas de Petri em triplicata. Este processo de diluição seriada é empregado para diminuir a concentração de ufc, tornando viável a contagem na placa de Petri.

As placas de Petri já semeadas com $1,35 \times 10^{4}$ ufc foram encaminhadas para a estufa e incubadas novamente por mais $48 \mathrm{~h}$ em atmosfera rica em dióxido de carbono $\left(5-10 \% \mathrm{CO}_{2}\right)$ pelo método da chama de vela. Passadas $48 \mathrm{~h}$, as placas foram analisadas por meio de contagem de ufc conforme ilustrado na Figura 3. 


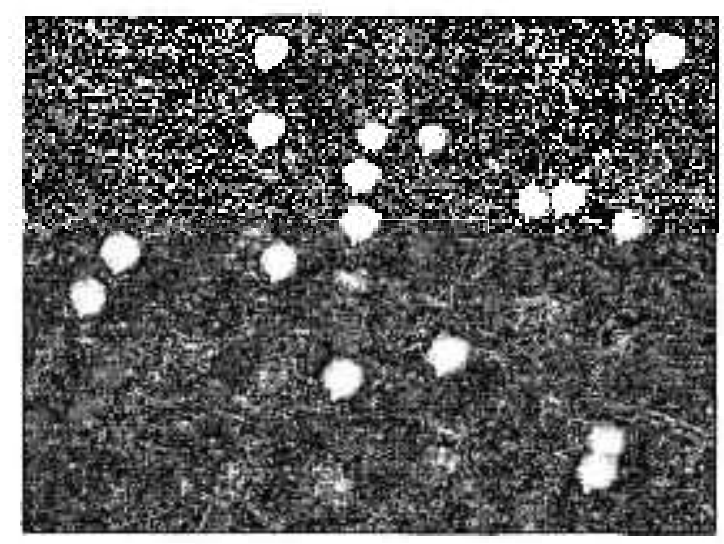

Figura 3 - Colônias de A. actinomycetemcomitans em TSA

As ufc encontradas na placa de Petri foram multiplicadas pelo fator de diluição mais uma multiplicação por 10 e após estas operações matemáticas, os resultados foram relacionados, comparando-os com o máximo de bactérias irradiadas, que foi de $1,35 \times 10^{8}$ ufc/mL. Os resultados obtidos passaram por análise estatística one-way ANOVA e comparação de médias por Tukey.

\subsection{Estudo in vivo}

\subsubsection{Aprovação do Comitê de Ética em Pesquisa}

Este projeto de pesquisa foi aprovado pelo Comitê de Ética em Pesquisa Animal do Instituto de Pesquisas Energéticas e Nucleares sob $n^{\circ} .02$. 


\subsubsection{Os animais}

Para indução de periodontite, foram selecionados 20 ratos machos (Rattus norvegicus, albinus, Wistar), adultos, SPF (Specific Pathogen Free), com massa corpórea semelhante de aproximadamente $300 \mathrm{~g}$. Os animais foram mantidos em miniisoladores individuais em um regime $12 \mathrm{~h} / 12 \mathrm{~h}$ de claro e escuro. Receberam ração granulada comercial e água antes e durante o periodo experimental ad libitum.

\subsubsection{A anestesia}

Em todas as intervenções com os animais, estes foram anestesiados intra-peritonealmente com dose de $0,15 \mathrm{~mL}$ de cloridrato de xilazina $2 \%$ (Farmabase Saúde Animal Ltda, Jaguariúna, Brasil) juntamente com $0,25 \mathrm{~mL}$ de cloridrato de cetamina $1 \%$ (Fort Dodge Animal Health, lowa, USA) permanecendo sob efeito sedativo por aproximadamente 90 minutos. 


\subsubsection{Indução da doença periodontal}

Os animais foram inicialmente submetidos a antibioticoterapia pela administração diária de $1 \mathrm{~mL}$ de ampicilina $50 \mathrm{mg}$ em suspensão junto a água dos bebedouros, durante 5 dias. Após 3 dias do término do antibiótico, foi iniciada a indução da doença periodontal nos animais ${ }^{50,51}$.

A indução foi realizada com a colocação de uma ligadura de algodão ao redor do segundo molar superior, embebidas em $1 \mathrm{~mL}$ de suspensão de $A$. actinomycetemcomitans $\left(1,2 \times 10^{9} \mathrm{ufc} / \mathrm{mL}\right)$. $O$ posicionamento correto das ligaduras foi obtido com o auxílio de uma lima endodôntica \#25 (Figura 4-A) para o afastamento dos dentes, e com isso, a passagem do fio (Figura 4-B). As ligaduras permaneceram por 15 dias para então serem removidas, sendo neste periodo nítida a avaliação clínica da periodontite. 

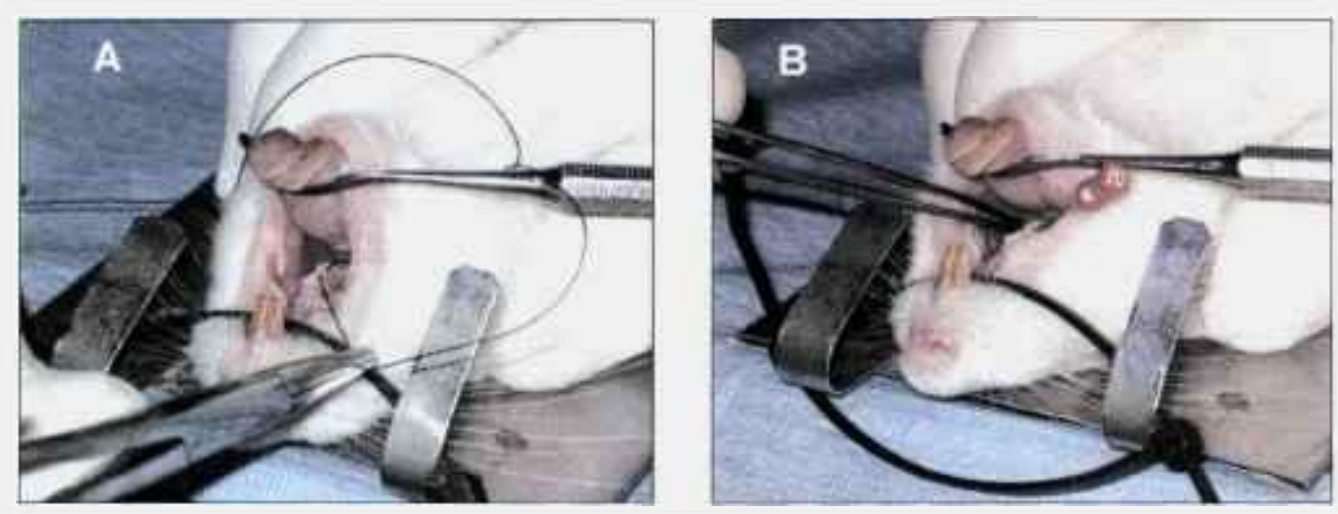

Figura 4 - (A) Utilização da lima endodôntica no afastamento dos molares superiores; (B) Colocação da ligadura ao redor do segundo molar

\subsubsection{Tratamentos}

Os animais foram divididos aleatoriamente em 2 grupos de tratamento.

- Grupo RM ( $n=10)$ - grupo remoção mecânica de placa.

- Grupo RM+PDT ( $n=10)$ - grupo remoção mecânica de placa + terapia fotodinâmica

A remoção mecânica de placa foi realizada com o auxílio de uma escova dental bitufo com movimentos vibratórios por $20 \mathrm{~s}$. As 
cerdas foram posicionadas a $45^{\circ}$ em relação ao dente (Figura 5-A). A inoculação do fotossensibilizador nas bolsas periodontais foi realizada com o auxílio de uma seringa com agulha hipodérmica descartável de $28 \mathrm{G}$ (agulha de insulina). A agulha foi inserida na bolsa periodontal, sendo então depositado o fotossensibilizador. A aplicação foi feita até o extravasamento da mesma pela bolsa. 0 corante aplicado topicamente permaneceu por cinco minutos (tempo de pré-radiação) diretamente nas bolsas periodontais (Figura 5-B). Após este tempo de pré-irradiação, as bolsas periodontais foram irradiadas com um laser de baixa potência, de emissão vermelha, $\lambda=660 \mathrm{~nm}, P=100 \mathrm{~mW}, E=5,4 \mathrm{~J}$ (Photon Lase, DMC equipamentos - São Carlos - Brasil), em movimentos de varredura ao redor do segundo molar superior (Figura $5-\mathrm{C}$ ). 

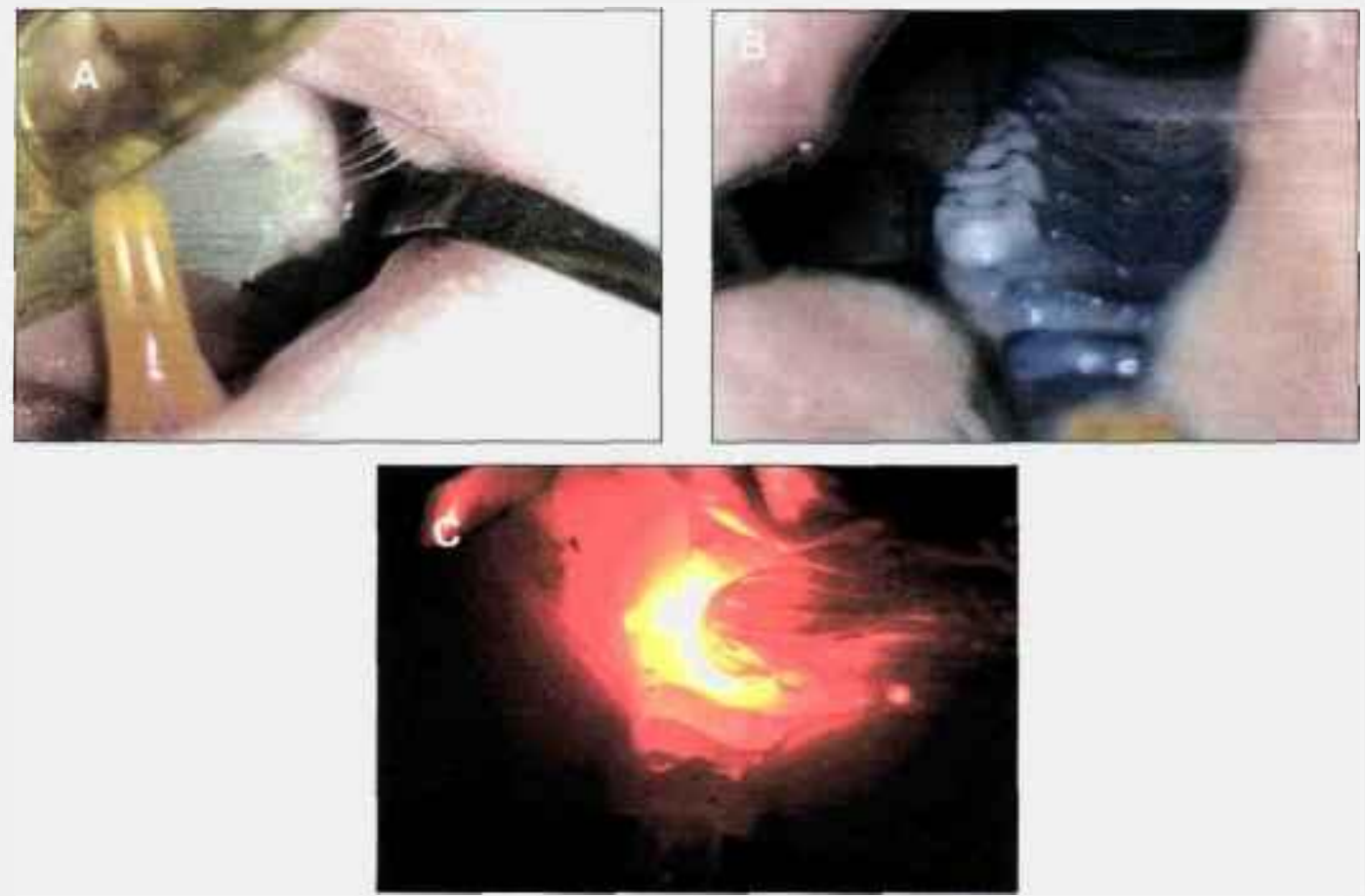

Figura 5 - (A) Remoção mecânica de placa em molares de ratos; (B) Bolsas periodontais ao redor de dentes molares de ratos preenchidas com azul de metileno a 0,01\%; (C) Irradiação da bolsa periodontal com o laser de emissão vermelha

\subsubsection{Coletas microbiológicas}

Foram realizadas coletas microbiológicas antes, imediatamente após o tratamento, dias 3 e 7 , em todos os grupos (Tabela 1). A coleta foi realizada pela inserção de duas pontas de papel absorvente $n^{0} \quad 15$ esterilizadas até 0 fundo das bolsas 
periodontais nas proximais (Figura 6-A). As pontas permaneceram aproximadamente 30 s nos sítios, sendo removidas e depositadas imediatamente em um frasco contendo $3 \mathrm{~mL}$ de meio de transporte - Viable Medium of Goteborg Anaerobic (VMGA III), contendo pérolas de vidro.

Os tubos contendo VGMA III (Figura 6-B) foram encaminhados em temperatura ambiente e manipulados no laboratório de Microbiologia Oral (ICB-USP), num período de até 4 horas após a coleta, para determinação do número de ufc de $A$. actinomycetemcomitans por amostra.
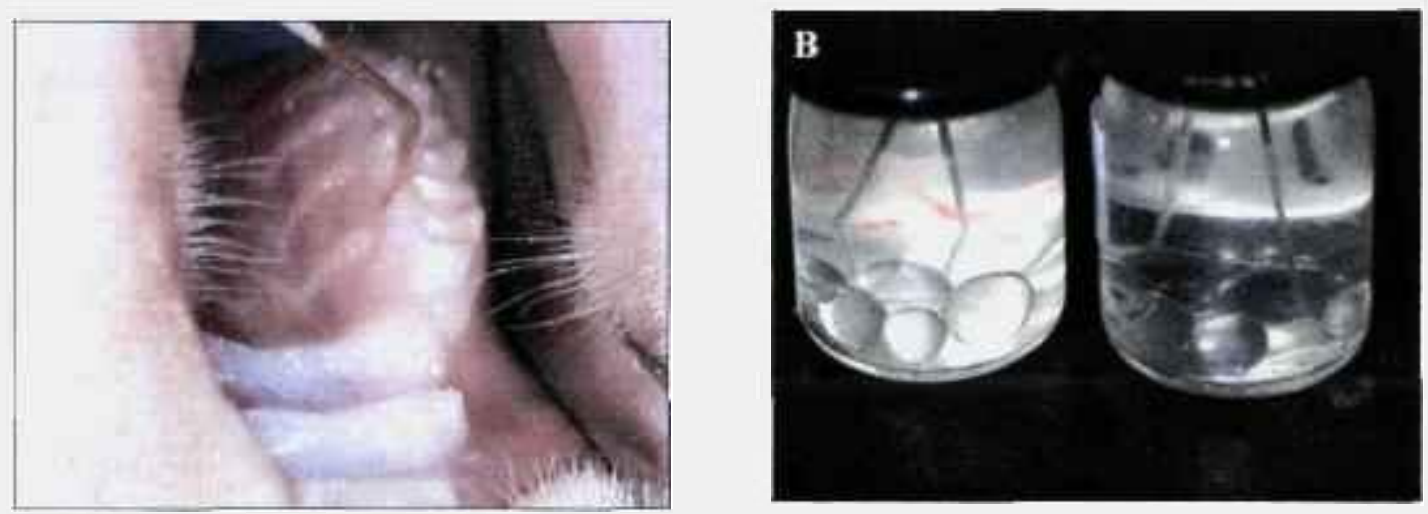

Figura 6 - (A) Coletas microbiológicas da bolsa periodontal

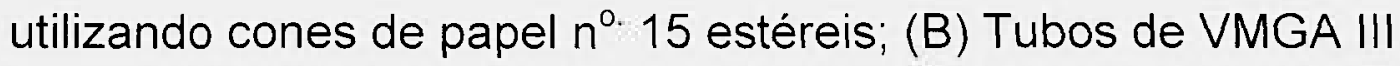


Tabela 1. Coletas microbiológicas das bolsas periodontais

\begin{tabular}{|c|c|c|c|c|}
\hline & Coleta 1 & Coleta 2 & Coleta 3 & Coleta 4 \\
\hline $\begin{array}{c}\text { Período } \\
\text { das coletas }\end{array}$ & $\begin{array}{c}\text { Antes do } \\
\text { tratamento } \\
\text { Dia 1 }\end{array}$ & $\begin{array}{c}\text { Após o } \\
\text { tratamento } \\
\text { Dia 1 }\end{array}$ & $\begin{array}{c}\text { Controle } \\
\text { Dia 3 }\end{array}$ & $\begin{array}{c}\text { Controle } \\
\text { Dia 7 }\end{array}$ \\
\hline
\end{tabular}

\subsubsection{Análise da microbiota por cultura}

Estes frascos foram incubados a temperatura de $37^{\circ} \mathrm{C}$, por 30 min, para promover a liquefação da gelatina, antes de serem manipulados. Em seguida, os tubos foram agitados em vórtex por 1 minuto e alíquotas de $100 \mu \mathrm{L}$ diluída em água peptonada $(\mathrm{pH} 7,2)$.

Alíquotas de $100 \mu \mathrm{L}$ de cada amostra não diluída e diluídas a $1 / 10$ e 1/100 foram semeadas em triplicata em placa de Petri, contendo TSA (Difco ${ }^{T M}, M D, E U A$ ) enriquecido com vancomicina (Sigma Chemical Co., St. Louis, Missouri, EUA), bacitracina (Sigma Chemical Co., St. Louis, Missouri, EUA) e soro de cavalo (TSBV). As placas foram incubadas a $37^{\circ} \mathrm{C}$, durante $72 \mathrm{~h}$ em condições de microaerofilia, através do método da chama de vela.

Após o periodo de incubação, foram selecionadas as placas contendo entre 30 e 300 colônias. Foi determinado o número de 
unidades formadoras de colônias de $A$. actinomycetemcomitans por amostra.

Colônias de cada amostra isolada foram observadas quanto as características morfológicas e de coloração, através do método de Gram. Também foram realizados testes de catalase. Os resultados foram submetidos à análise estatística ANOVA $(p<0,05)$.

4.3.8. Análise da microbiota por reação de polimerase em cadeia (PCR)

\subsubsection{Extração de DNA}

Após 0 desenvolvimento das culturas de $A$. actinomycetemcomitans padrão e isolados clínicos em placas de TSBV, três colônias de cada placa foram recolhidas e inseridas isoladamente em tubo de centrifuga de $1,5 \mathrm{~mL}$ contendo $100 \mu \mathrm{L}$ de solução TE (10 mM Tris $\mathrm{Cl}$ - pH 7,4; 7,5 ou 7,8; 1 mM EDTA - pH 8,0). Alíquota de $44 \mu \mathrm{L}$ da suspensão TE foi transferida para tubo de PCR e adicionados $5 \mu \mathrm{L}$ de Tween 20 a $5 \%$ e $1 \mu \mathrm{L}$ de solução de Proteinase $\mathrm{K} 10 \mathrm{mg} / \mathrm{mL}$. As amostras foram inseridas em termociclador (MJ Research, Minnesota, Minneapolis, EUA) e 
incubadas a $55^{\circ} \mathrm{C}$ por 2 horas e a $95^{\circ} \mathrm{C}$ por 10 minutos para extração de DNA.

\subsubsection{Amplificação da região 16SrRNA do $A$. actinomycetemcomitans por PCR}

O DNA das amostras foi utilizado como molde em reação PCR padrão para amplificação da região 16SrRNA utilizando os iniciadores espécie-específicos para $A$. actinomycetemcomitans Os oligonucleotídeos utilizados apresentaram as seguintes seqüências: 5' - GTTTAGCCCTGGTGCCCGAAG- 3' (forward primer); 5' TGACGGGCGGTGTGTACAAGG - 3' (reverse primer) (Invitrogen, São Paulo, São Paulo, Brasil) ${ }^{52}$.

Para cada reação de amplificação da região $16 S r R N A$ foram utilizados: $5 \mu \mathrm{L}$ de DNA molde das amostras clínicas, $25 \mathrm{nmol}$ de cada primer, $5 \mathrm{mM}$ de cada dNTP, 2,5U de Taq polimerase (Invitrogen, São Paulo, São Paulo, Brasil), 2,5 $\mu \mathrm{L}$ de tampão (10X), cloreto de magnésio na concentração final de $0,75 \mathrm{mM}$ e água Milli Q estéril para $25 \mu \mathrm{L}$ de volume total de reação. $O$ controle positivo 
constituiu-se da reação padrão acrescida de $1 \mu \mathrm{L}$ de DNA de $A$. actinomycetemcomitans (HK 1651). O controle negativo foi constituído da reação padrão sem adição do DNA molde. As condições de termociclagem (MJ Research, Minnesota, Minneapolis, EUA) seguidas foram: desnaturação inicial a $95^{\circ} \mathrm{C}$ por 5 minutos, seguindo-se 25 ciclos constituídos de: desnaturação a $95{ }^{\circ} \mathrm{C}$ por 30 segundos, anelamento a $55^{\circ} \mathrm{C}$ por 30 segundos e extensão a $72{ }^{\circ} \mathrm{C}$ por 45 segundos e um ciclo de extensão final de $72{ }^{\circ} \mathrm{C}$ por $5 \min ^{52}$.

Os produtos da reação de PCR foram submetidos à corrida eletroforética em gel de agarose a 1,5\% (Sigma Chemical Co, St Louis, EUA) a $70 \mathrm{~V}$, em tampão Tris Acetato EDTA (TAE - Tris acetato $40 \mathrm{mM}, \mathrm{pH} 8,5$; EDTA $2 \mathrm{mM}$ ) e corados com brometo de etídio sendo fotografados sob luz ultravioleta (EPSON, Hemel Hempstead, Hertforshise, Inglaterra). As reações que apresentaram banda única com tamanho esperado (547 bp) foram consideradas positivas para a espécie. 
RESULTADOS 


\section{RESULTADOS}

\section{1- Espectroscopia}

A análise da espectroscopia de absorção obtida do AM entre a região de $500 \mathrm{~nm}$ e $700 \mathrm{~nm}$ apresenta duas bandas de absorção na região do vermelho (centrada em $\lambda=607 \mathrm{~nm}$ - dímero e $\lambda=$ 663nm- monômero). Com relação ao espectro da suspensão bacteriana, não há absorção na região visivel. Quando da análise do conjunto $\mathrm{AM}$ e suspensão de $A$. actinomycetemcomitans, observa-se que a presença do microorganismo interfere na banda de absorção do AM, diminuindo a absorção do fotossensibilizador, porém, a banda na região do vermelho continua centrada em $\lambda=$ $663 \mathrm{~nm}$, ressonante ao comprimento de onda da fonte de luz utilizada neste estudo (Figura 7A).

A figura 7B mostra a absorção normalizada sem o espectro da suspensão bacteriana. A diminuição na intensidade observada (efeito hipocrômico) é devido à presença do DNA bacteriano, que absorve na região do UV e não absorve luz no visível. 


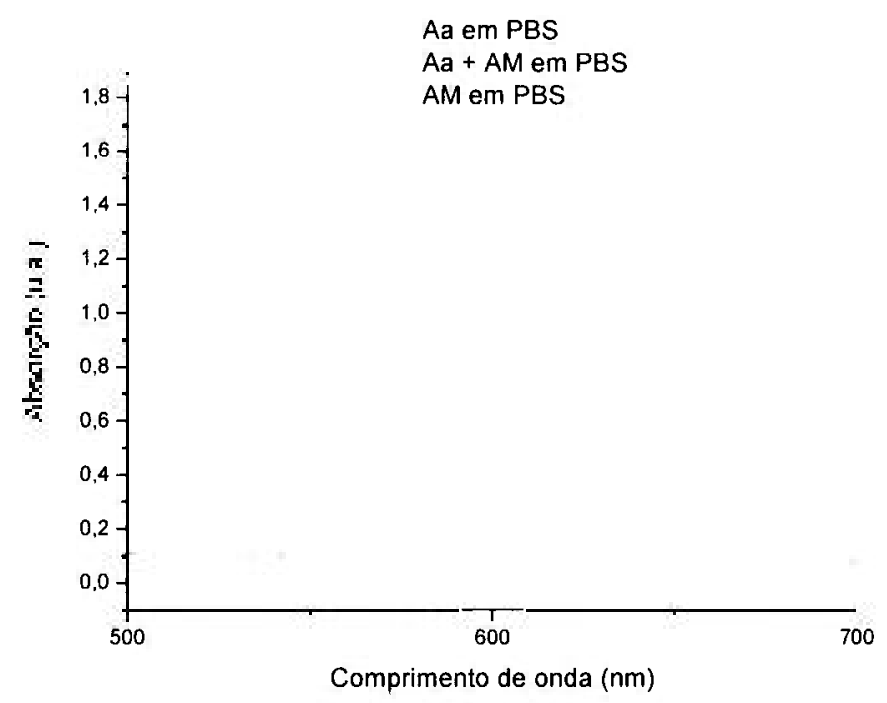

Figura 7A - Espectros de absorção na região visivel da solução de azul de metileno, AM com $A$. actinomycetemcomitans e suspensão bacteriana sozinha $(\approx 300 \mu \mathrm{M})$.

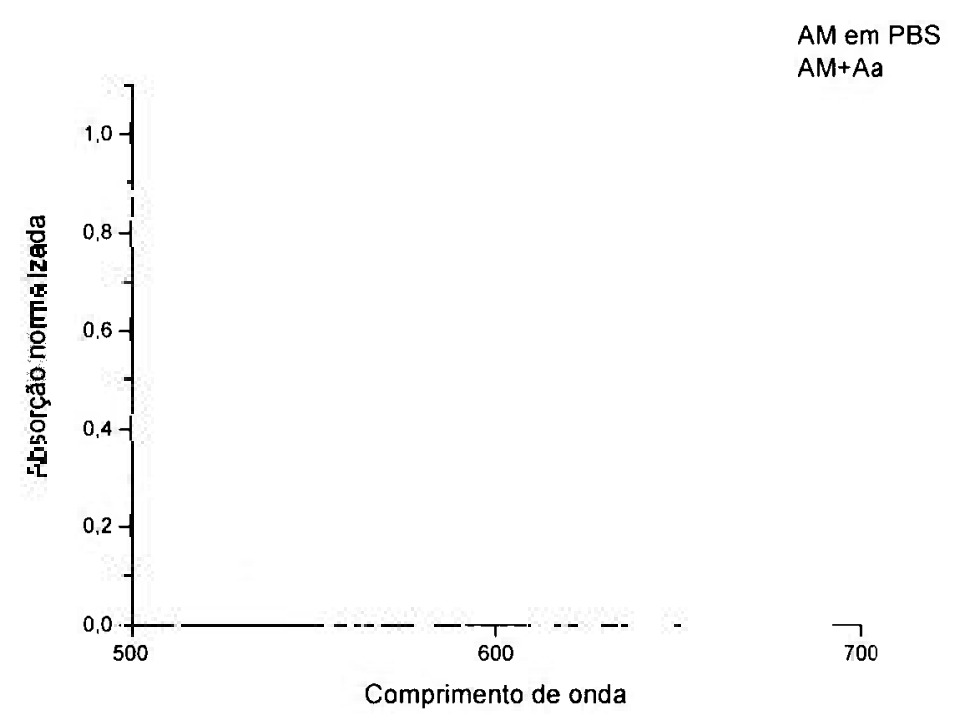

Figura 7B - Absorção normalizada na região visivel da solução de azul de metileno e AM com $A$. actinomycetemcomitans $(\approx 300 \mu \mathrm{M})$. Note o efeito hipocrômico devido à presença do DNA bacteriano. 


\subsection{Estudo in vitro}

O grupo L-AM- e o grupo L+AM- não apresentaram redução de $A$. actinomycetencomitans. $O$ mesmo resultado foi obtido no grupo L-AM+, sugerindo que somente a presença do fotossensibilizador, sem a irradiação com o laser de baixa potência, não causa redução das colônias bacterianas. Além disto, este achado sugere que não há toxicidade do azul de metileno a $0,01 \%$. Por outro lado, os grupos L5,4+AM+ e L9+AM+ apresentaram uma significante redução na contagem de colônias viáveis quando comparados aos outros grupos (Figura 8 e Tabela 2). Entre os grupos onde a PDT foi utilizada, não foram observadas diferenças estatísticas significantes. É possível observar da Figura 8 e da Tabela 2, que o fotossensibilizador em ambas os tempos de irradiação foram eficientes em reduzir significativamente o número de ufc de $A$. Actinomycetemcomitans, porém sem diferença estatística significante entre os grupos (ANOVA, $p>0,05$ ). 


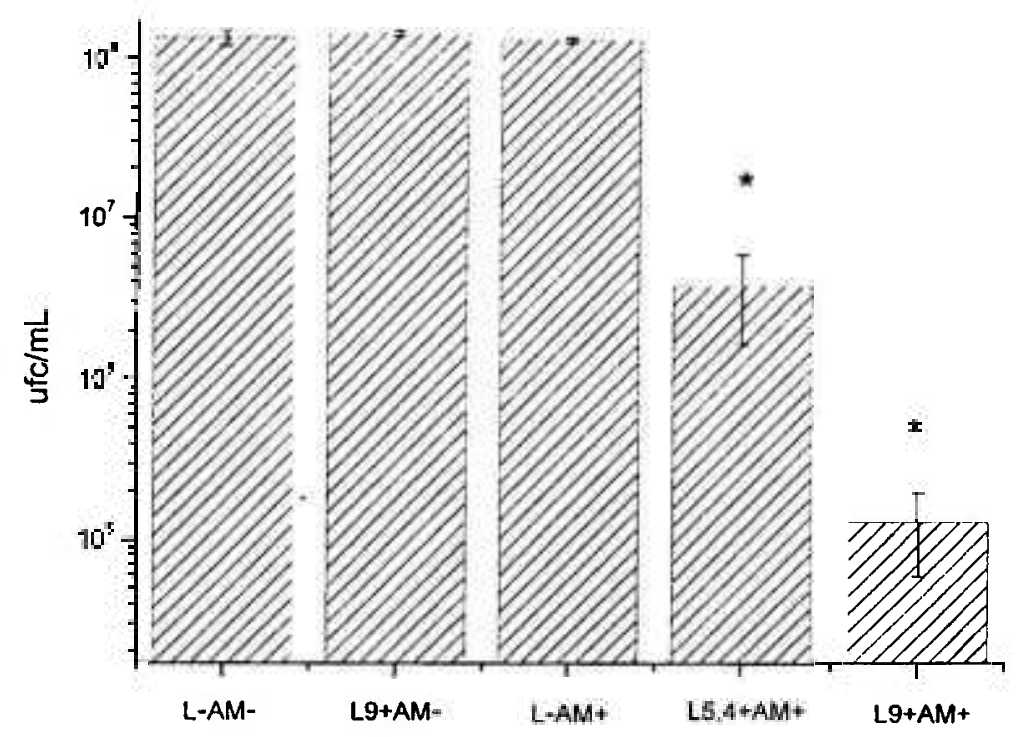

Figura 8 - Valores médios \pm erro padrão de ufc/mL para todos os grupos experimentais ( ${ }^{*}$ não há diferença estatística significante)

Tabela 2 - Percentual de redução bacteriana nos grupos PDT Grupos PDT Redução bacteriana L5,4+AM+ $98,4 \%$ 


\subsection{Estudo in vivo}

Após 15 dias ao início da indução da periodontite com ligadura e suspensão de $A$. actinomycetemcomitans, para ambos os grupos, observou-se clinicamente o sangramento gengival e por sondagem a presença de bolsa periodontal (Figura 9).

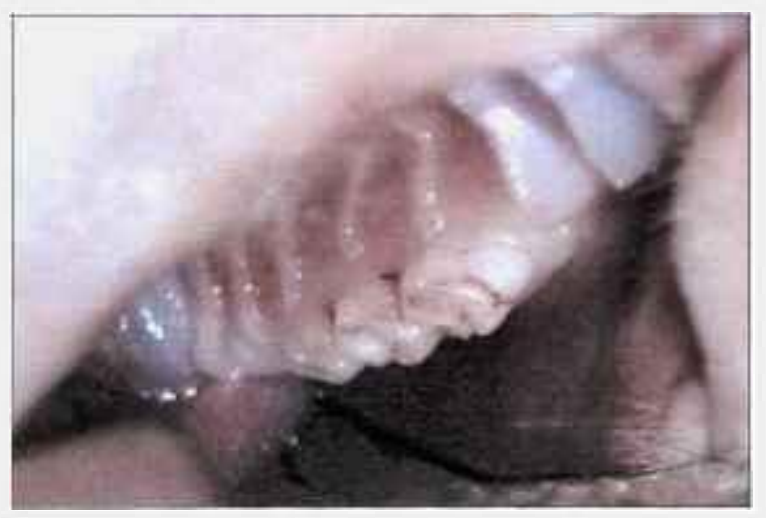

Figura 9 - Periodontite induzida nos molares da maxila de ratos

\subsubsection{Análise da microbiota por cultura}

Foram realizadas coletas microbiológicas de 20 animais nos quais foi induzida doença periodontal. As coletas foram realizadas em momentos distintos do tratamento, portanto 40 amostras foram 
coletadas no grupo RM e 40 no grupo $R M+P D T$, as quais foram processadas para análise por cultura e PCR.

A cultura destinou-se a determinação do número total de ufc de $A$. actinomycetemcomitans por amostra. A Figura $10-A$ exibe 0 número de ufc/mL para todas as coletas, enquanto a Figura 10-B demonstra o número de $\mathrm{ufc} / \mathrm{mL}$ do $A$. actinomycetemcomitans para os grupos RM e RM+PDT antes e depois do tratamento (coleta 1 e 2). Observa-se que antes do tratamento os dois grupos não apresentaram diferenças significantes entre si, o que sugere que o número de $A$. actinomycetemcomitans era igual para ambos os grupos. Os tratamentos foram eficazes em reduzir $A$. actinomycetemcomitans, já que há diferença estatística significante entre antes e depois do tratamento.

Comparando-se os tratamentos, observa-se que o grupo RM+PDT apresenta uma redução significantemente maior comparada ao grupo RM, o que indica que a PDT é capaz de aperfeiçoar a terapêutica periodontal. Em termos percentuais, a redução bacteriana nas bolsas periodontais foi de $87,7 \%$ para o grupo RM e de $93,5 \%$ quando a RM foi associada à PDT (Figura 10-C).

No dia 3 é possivel observar um decréscimo de $A$. actinomycetemcomitans para ambos os grupos em relação ao 
momento anterior, mas sem diferenças significativas entre eles. No dia 7 , há um aumento no número de microorganismos, ou seja, uma recolonização, que é significantemente diferente do dia 3 . Comparando-se os grupos RM e RM+PDT, nenhuma diferença estatística significante foi observada.

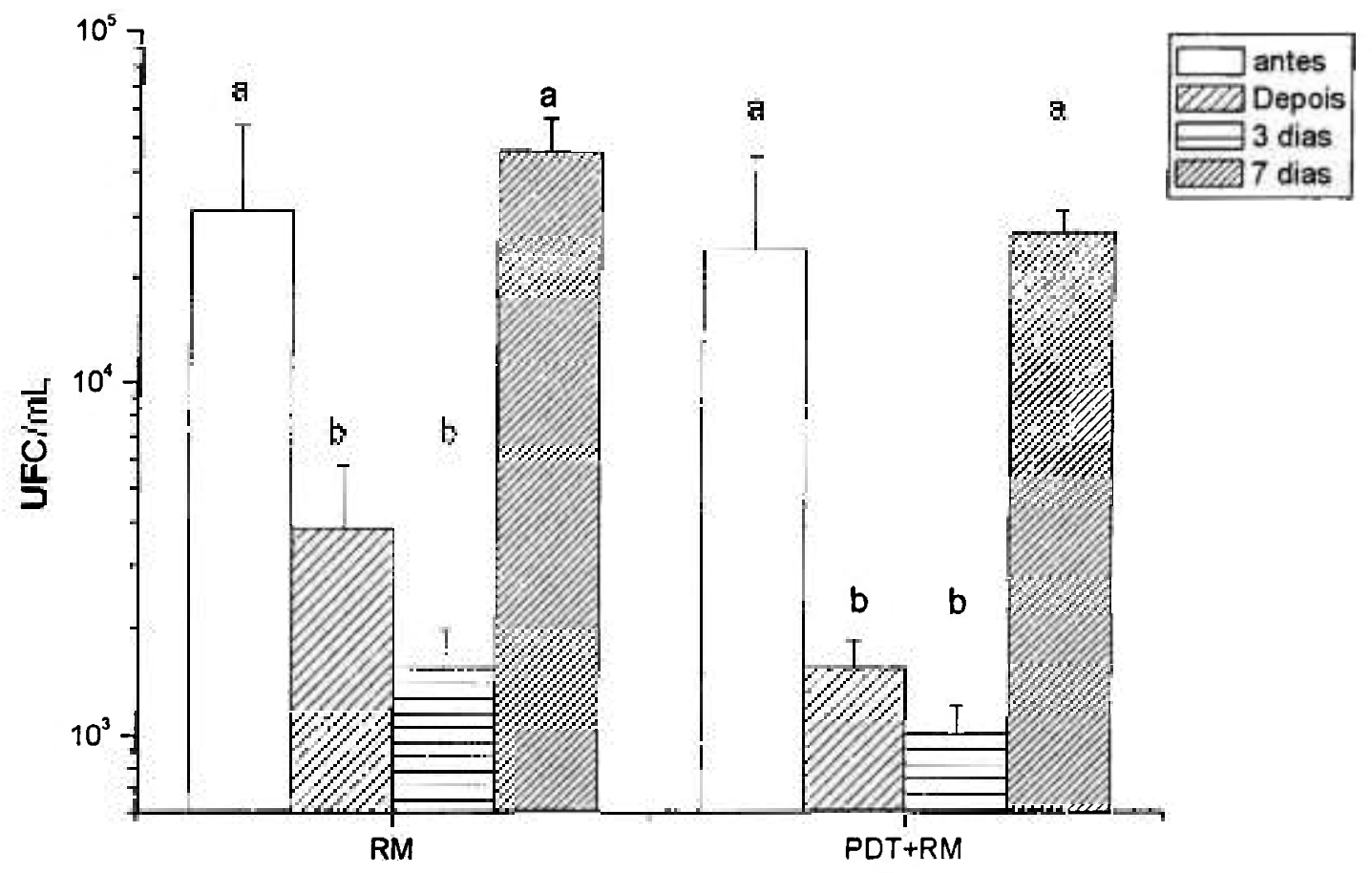

Figura 10A- Valores médios \pm desvio padrão de $\mathrm{ufc} / \mathrm{mL}$ para os grupos experimentais. a e b mostram diferenças significantes entre momentos e grupos. 


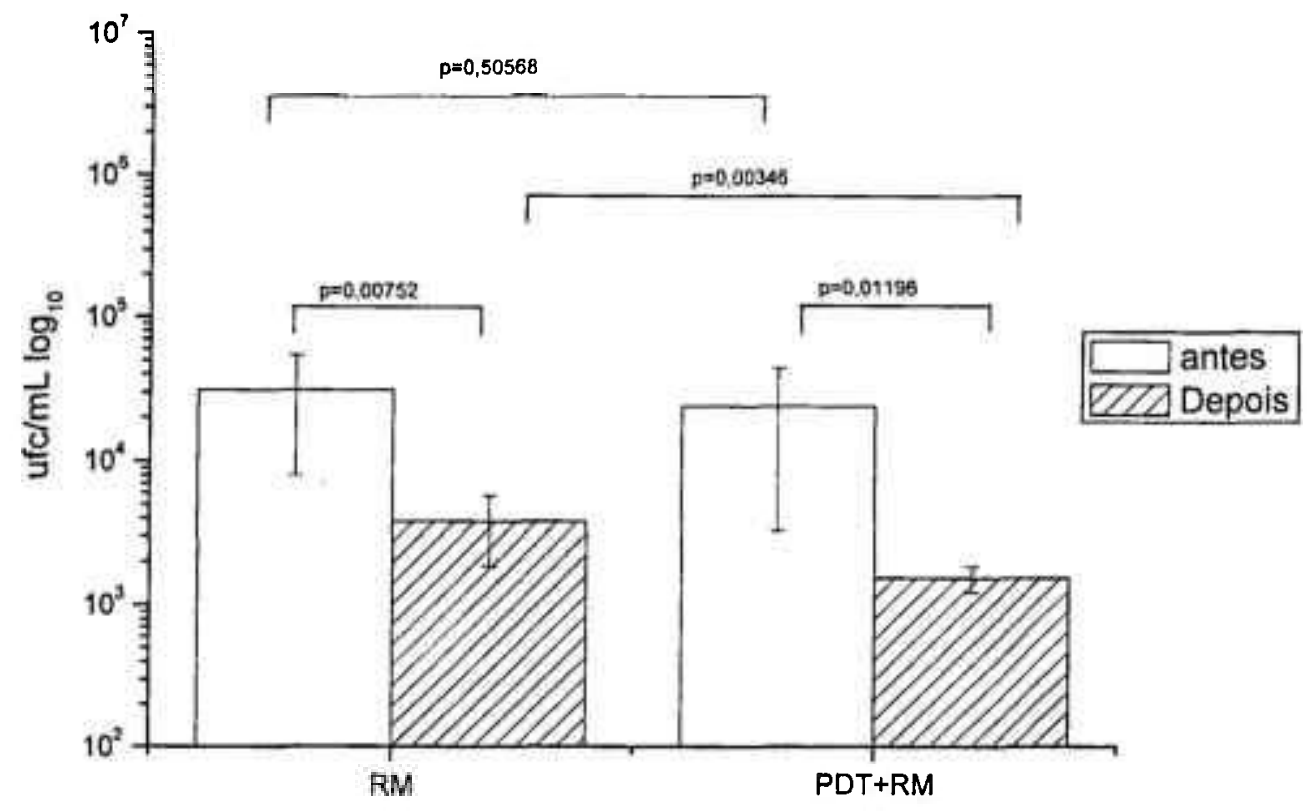

Figura 10B- Valores médios \pm desvio padrão de ufc/mL para as coletas 1 e 2

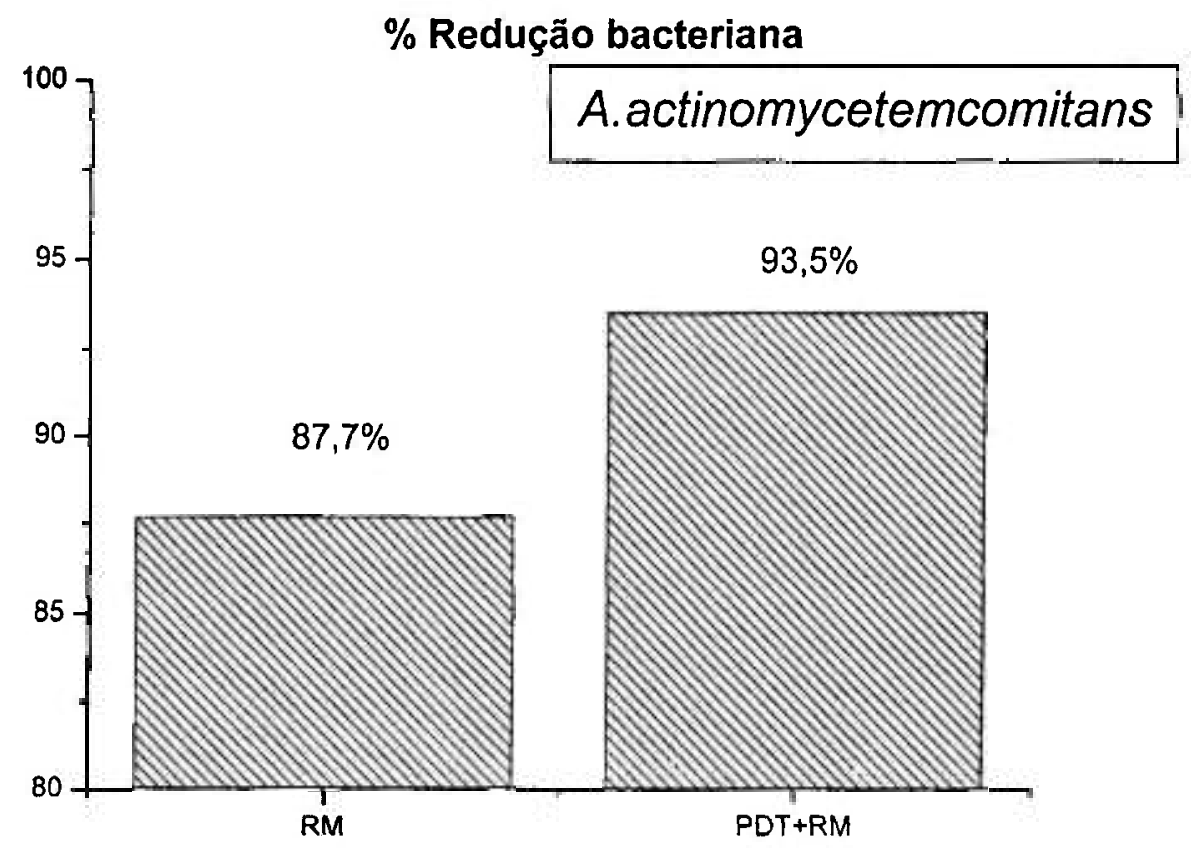

Figura 10C- Percentuais de redução de A. actinomycetemcomitans imediatamente após os tratamentos 


\subsubsection{Análise da microbiota por reação de polimerase em cadeia (PCR)}

A reação de PCR para deteç̧ão de $A$. Actinomycetemcomitans foi realizada usando como molde o DNA da amostra padrão comparado com as amostras obtidas nas diferentes fases do tratamento. As reações de polimerase em cadeia realizadas apresentaram banda única com tamanho esperado (547 bp) sendo, portanto, consideradas positivas para a espécie, confirmando que o DNA das colônias isoladas de cada uma das coletas era realmente pertencentes a espécie $A$. Actinomycetemcomitans (Tabela 3). Alem disso, é possível observar que apos o tratamento (coleta 2) e nos dias 3 (coleta 3) e 7 (coleta4), houve a confirmação da espécie. A Figura 11 exibe representativamente os produtos da reação de PCR da amostra padrão e isolado clínico submetidos à corrida eletroforética em gel de agarose a $1,5 \%$. 


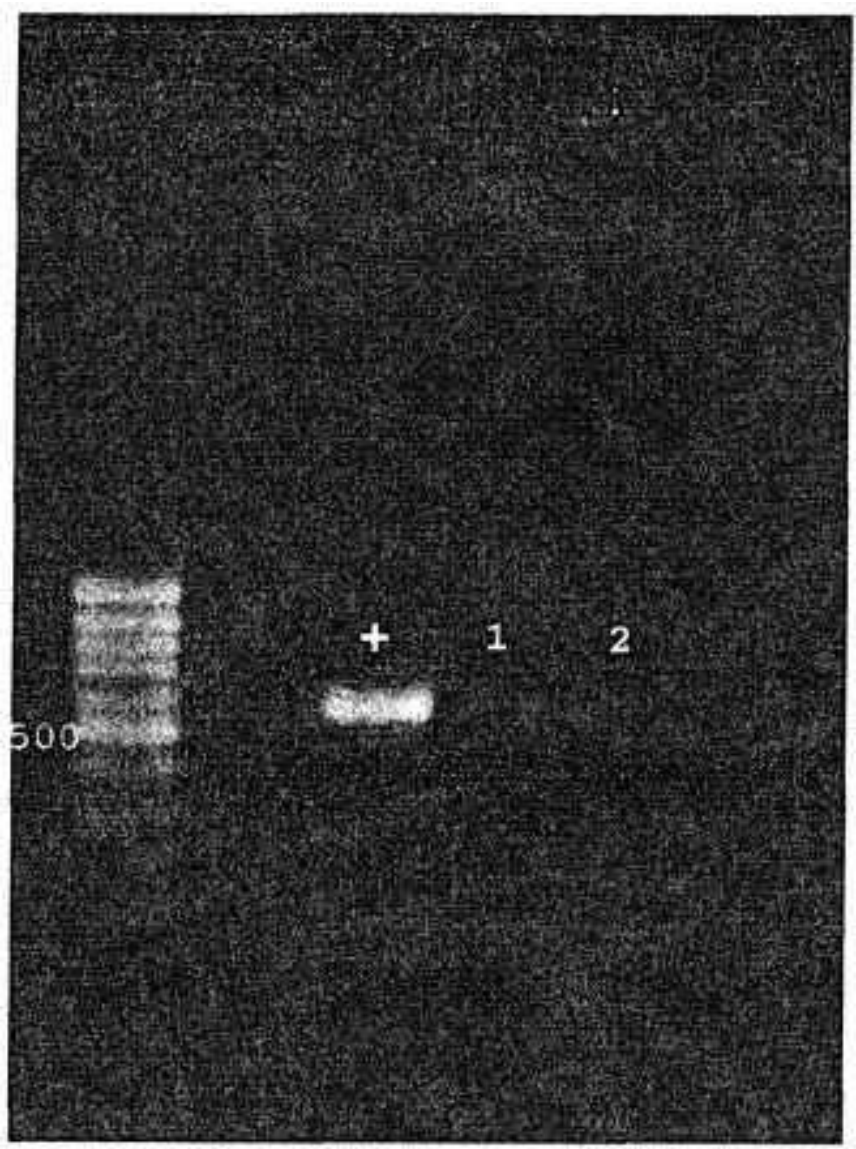

Figura 11 - Reação de PCR da amostra padrão (+), isolados clínicos (1 e 2) após corrida eletroforética

Tabela 3 - Resultados das análises da microbiota por PCR

\begin{tabular}{c|c|c|c|c}
\hline & Coleta 1 & Coleta 2 & Coleta 3 & Coleta 4 \\
\hline Grupo RM & + & + & + & + \\
\hline Grupo RM+PDT & + & + & + & + \\
\hline
\end{tabular}




\section{DISCUSSÃO}




\section{DISCUSSÃO}

Bactérias Gram-negativas são mais resistentes à PDT. Esta resistência é atribuída à membrana externa, que serve como barreira à penetração de substâncias lipofilicas. A utilização de um corante catiônico mostra maior atividade fotodinâmica contra bactérias Gram-negativas, já que a carga positiva promove uma ligação eletrostática à superfície externa da célula, induzindo um dano inicial que favorece a penetração do corante ${ }^{53}$.

Chan \& Lay avaliaram o comprimentos de onda $665 \mathrm{~nm}$ juntamente com o azul de metileno na redução in vitro do número de A. Actinomycetemcomitans. Os autores observaram que 0 comprimento de onda utilizado no experimento apresentou eficiência na redução bacteriana quando associado ao fotossensibilizador, porém, $A$. actinomycetemcomitans foi menos sensivel à terapia ${ }^{14}$. Nossos resultados diferem dos de Chan \& Lay, que observaram uma redução de $95 \%$ para $0 A$. actinomycetemcomitans com um tempo de irradiação de 1 min e uma energia de $6 \mathrm{~J}$. Neste estudo, o mesmo fotossensibilizador e a mesma concentração foram utilizados. Provavelmente, os diferentes resultados podem ser explicados pelos outros parâmetros usados neste estudo. 
Outros fotossensibilizadores como o $\mathrm{AOT}^{54}$, também uma fenotiazina, e o clorina $e 6^{55}$ já foram testados frente a este microorganismo, porém sem resultados expressivos ${ }^{14}$.

A relação entre comprimento de onda emitido pelo laser e o espectro de absorção do AM é essencial para que os efeitos fotoquímicos/fotofísicos ocorram, visto que a luz deve emitir um comprimento de onda ressonante à banda de absorção do corante. Pela espectroscopia podemos observar que o comprimento de onda utilizado nesta pesquisa $(\lambda=660 \mathrm{~nm})$ está ressonante a uma das duas bandas de absorção encontradas $(\lambda=663 \mathrm{~nm})$. Em estudo recente de Usacheva e col. ${ }^{21}$, os autores relatam que este pico de absorção em $\lambda=663 \mathrm{~nm}$ está relacionado com o monômero, porém eles sugerem que os dímeros $(\lambda=607 \mathrm{~nm})$ e os agregados também podem ser responsáveis pelos processos de fotooxidação. Além disso, foi possível observar um efeito hipocrômico na absorção do $A M+A a$, que é devido à presença do DNA bacteriano. É sugerido que a diminuição da intensidade de absorção na região do visivel decorre da forte interação entre os estados eletrônicos do cromóforo intercalado às bases do DNA ${ }^{40}$. Estes achados indicam que o tempo de pré-irradiação de 5 min foi suficiente para o AM ser incorporado pelo microorganismo. 
São muitas as variáveis que influenciam no resultado da terapia fotodinâmica. Devido a esta diversidade de variáveis, a simples transferência dos achados de redução bacteriana in vitro para a clínica podem não apresentar os mesmos resultados. Esta comprovação foi observada em nosso estudo in vivo, onde foi obtida uma redução de $93,5 \%$ quando associamos o tratamento convencional, ou seja, a remoção mecânica da placa bacteriana concomitante à terapia fotodinâmica. Estes achados estão de acordo com recentes resultados obtidos em estudo in vitro, que avaliou a interferência de produtos biológicos (saliva e sangue) que podem causar desvio e alterações das bandas de absorção ${ }^{56}$.

Analisando os resultados da associação das terapias frente ao tratamento convencional de periodontite, fica notório o benefício que a PDT trouxe para a redução de $A$. actinomycetemcomitans. A diferença de redução microbiana entre os grupos foi estatisticamente significante, visto que com a aplicação da PDT obtivemos uma redução maior que $1 \mathrm{log}$, fato não ocorrido com o grupo RM. Isto representa uma diferença na resposta clínica muito expressiva, pois o A. actinomycetemcomitans é responsável pela sintetização de uma leucotoxina que destrói neutrófilos e monócitos e uma substância que inativa as células $T$ supressoras. Os dois fatores podem prejudicar a defesa antibacteriana gengival, além de 
produzir fatores que reduzem a proliferação de fibroblastos e células endoteliais e epiteliais, afetando assim a capacidade de resposta do periodonto à irritação ${ }^{1}$. Outro fator preponderante para a redução de células viáveis de $A$. actinomycetemcomitans é que este microorganismo está relacionado a uma série de doenças sistêmicas como infarto agudo do miocárdio, bacteremias transitórias e endocardites bacterianas ${ }^{57}$.

Clinicamente, a possibilidade de obtermos uma maior efetividade da terapêutica periodontal, é considerada um grande beneficio, principalmente para pacientes com dificuldade de higienização, ou seja, pacientes portadores de alguma deficiência física ou mental, além de pacientes usuários de próteses e aparelhos ortodônticos ${ }^{58}$.

Em recente estudo realizado em nosso grupo, compararam-se os efeitos da terapia fotodinâmica com a terapia convencional, utilizando irrigação com clorexidina a 0,12\% e cirurgia a retalho, na redução microbiana de periimplantite induzida em mandibula de cães. Os resultados mostraram que as duas terapias foram significantemente eficientes em reduzir microorganismos, embora não se tenha observado diferença estatística significante entre os grupos $^{7}$. Assim como a periimplantite, a periodontite quando não solucionada com a raspagem e o alisamento radicular, a cirurgia a 
retalho torna-se o tratamento de eleição na tentativa de solucionar a infecção. É importante ressaltar que a cirurgia a retalho é um método invasivo, doloroso, trazendo assim, desconforto ao paciente.

A recolonização encontrada em nosso estudo no dia 7 já era esperada, devido à falta de controle da higienização bucal dos animais. Este fato, quando extrapolado à rotina clínica do cirurgiãodentista, serve de alerta para que este conscientize seu paciente da importância da colaboração na higienização diária ${ }^{4}$.

A análise por PCR confirmou a presença do $A$. actinomycetemcomitans em todas as coletas microbiológicas. Por esta razão tem-se a certeza de que as ufc identificadas pelo método de cultura realmente eram representantes da espécie em questão, excluindo qualquer possibilidade de estarmos avaliando colônias provenientes de outro microorganismo que apresentassem aspectos morfológicos semelhantes ao A. actinomycetemcomitans. Mesmo não obtendo uma redução de $A$. actinomycetemcomitans de 99,9\%, como visto nos estudos in vitro, o significante aumento de redução conseguido com a utilização da terapia fotodinâmica coadjuvante à terapêutica convencional, diminui a possibilidade de se indicar uma intervenção cirúrgica ou a aplicação de uma terapêutica medicamentosa. 
CONCLUSÃO 


\section{CONCLUSÃO}

- O fotossensibilizador AM não alterou sua banda de absorção na presença da suspensão bacteriana, apesar de ser observada uma diminuição na intensidade da banda devido à presença da bactéria.

- $\quad$ fotossensibilizador azul de metileno associado ao comprimento de onda de $660 \mathrm{~nm}$ e com energias de $5,4 \mathrm{~J}$ e $9 \mathrm{~J}$ apresentou eficiência na redução de $A$. actinomycemtecomitans.

- A metodologia desenvolvida para a indução da periodontite agressiva com o uso de ligaduras embebidas em $A$. actinomycemtecomitans mostrou-se eficaz.

- O uso da terapia fotodinâmica como coadjuvante à terapêutica periodontal mostrou-se como uma boa alternativa na redução de $A$. actinomycemtecomitans. 


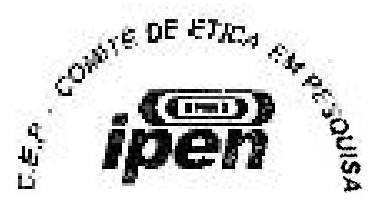

\section{Parecer - Projeto $N^{\circ}$ 2/CEPA-IPEN/SP}

Com base nos pareceres apresentados pelos relatores, o protocolo de pesquisa ESTUDO DOS EFEITOS DA TERAPIA FOTODINÁMICA EM PERIODONTITE INDUZIDA EM RATOS de responsabilidade do pesquisador MARTHA SIMŐES RIBEIRO foi considerado APROVADO.

Tendo em vista a legislaçăo vigente, devem ser encaminhados, a este Comitè, relatórios anuais (parciais ou finais, dependendo da duração do projeto) referentes ao andamento da pesquisa. Após o término da pesquisa, uma cópia do trabalho, em CD ou disquete, deve ser encaminhada a este CEPA

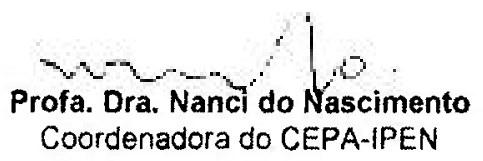

COMITEE DE ETICA EM PESQUISA ANIMAL

Av Prof Lineu Prestes, 2242 - Cidade Universitária - CEP 05508-000 - Săo Paulo - SP

Teletone: (011) 3816-9229 - Fax (011) 3816-9232

E-mail: nnascime@ipen br 
REFERÊNCIAS BIBLIOGRÁFICAS 


\section{REFERÊNCIAS BIBLIOGRÁFICAS}

1 SLOTS, J \& TING, M. Actinobacillus actinomycetemcomitans and Porphyromonas gingivalis in human periodontal disease: occurrence and treatment. Periodontology 2000. v.20, p.82-121, 1999.

${ }^{2}$ ISHIKAWA, I. \& BAEHNI, P. Nonsurgical periodontal therapy - where do we stand now?. Periodontology 2000. V.36, p.9-13, 2004.

${ }^{3}$ HAFFAJEE, A. \& SOCRANSKY, S.S. Microbiology of periodontal diseases: introduction. Periodontology 2000. v.38, p.9-12, 2005.

${ }^{4}$ HAFFAJEE, A.; TORRESYAP, G.; SOCRANSKY, S.S. Clinical changes following four different periodontal therapies for the treatment of chronic periodontitis: 1-year results. J. Clin. Periodontol. V.34, p.243-253, 2007.

${ }^{5}$ WALKER, C.B.; KARPINIA, K.; BAEHNI, P. Chemotherapeutics: antibiotics and other antimicrobials. Periodontology 2000. V.36, p.146-165, 2004.

6 ZANIN, I.C.J.; BRUGNERA JR., A.; HOFLING, J.F.; ZANIN, F.A.A.; GONÇALVES, R.B. Antimicrobial effect of low-level laser therapy in the presence of photosensitizer on humam saliva bacteria. Lasers in Dentistry VIII, P. Rechman, D. Fried, T. Henning, eds. Proc. SPIE, 4610;p.162-169, 2002. 
7 HAYEK, R.R.A.; ÁRAÚJO, N.S.; GIOSO, M.A.; FERREIRA, J.; BAPTISTASOBRINHO, C.A.; YAMADA JUNIOR, A.M.; RIBEIRO, M.S. . Comparative study between the effects of photodynamic therapy and conventional therapy on microbial reduction in ligature induced peri-implantitis in dogs. J.Periodontol. v.76, p.1275-81, 2005.

${ }^{8}$ HAYEK, R.R.A.; YAMADA JR., A.M.; GARCEZ, A.S.; NÚÑEZ, S.C.; SUZUKI, L.C.; RIBEIRO, M.S. Comparison between photodynamic therapy and a bactericidal solution in the treatment of dental alveolitis - microbiological evaluation. Braz Dental J. 15, p.110, 2004.

${ }^{9}$ DORTBUDAK, O.; HAAS, R.; BERNHART, T.; MAILATH-POKORNY G. Lethal photosensitization for decontamination of implant surfaces in the treatment of peri-implantitis. Clin Oral Implants Res. V.12, p.104-108, 2001.

10 WILSON, M.; BURNS, T; PRATTEN, J.; PEARSON, G.J. Bacteria in supragingival plaque samples can be killed by low-power laser light in the presence of a photosensitizer. J App/ Bacteriol. V.78, p.569-574, 1995.

${ }^{11}$ SOUKOS, N.S.; WILSON, M.; BURNS, T.; SPEIGHT, P.M. Photodynamic effects of toluidine blue on human oral keratinocytes and fibroblasts and Streptococcus sanguis evaluated in vitro. Lasers Surg Med. V.18, p.253-259, 1996. 
12 PRATES, R.A.; YAMADA JR., A.M.; SUYUKI, L.C.; HASHIMOTO, M.C.E.; CAI, S.; GOUW-SOARES, S.; GOMES, L.; RIBEIRO, M.S. Bactericidal effect of malachite green and red laser on Actinobacillus actinomycetemcomitans. J. Photochem. Photobiol. B. v.86, p.70-76, 2007.

${ }^{13}$ CHAN, Y. \& LAI, C. Bactericidal effects of different laser wavelengths on periodontopathic germs in photodynamic therapy. Laser Med Sci. V.18, p.5155, 2003.

14 NUNN, M.E. Understanding the etiology of periodontitis: an overview of periodontal risk factors. Periodontology 2000. V.32, p.11-23, 2003.

${ }^{15}$ EZZO, P.J. \& CUTLER, C.W. Microoranisms as risk indicators for periodontal disease. Periodontology 2000. V.32, p.24-35, 2003.

${ }^{16}$ ARMITAGE, GC. Clinical evaluation of periodontal diseases. Periodontology 2000. V.7, p. 39-53, 1995.

17 ARMITAGE, GC. Periodontal diagnoses and classification of periodontal diseases. Periodontology 2000. V.34, p. 9-21, 2004.

${ }^{18}$ ALBANDAR, J.M. Periodontal diseases in North América. Periodontology 2000. V.29, p.31-69, 2002. 
${ }^{19}$ SOCRANSKY, S.S.; HAFFAJEE, A.D.; GOODSON, J.M.; LINDHE, J. New concepts of destructive periodontal disease. J. Clin. Periodontol. V.11, p.21-32, 1984.

${ }^{20}$ LANG, N.; BARTOLD, P.M.; CULLINAN, M.; JEFFCOAT, M.; MOMBELLI, A.; MURAKAMI, S.; PAGE, R.; PAPAPANOU, P.; TONETTI, M.; VAN DYKE T. Consensus report: aggressive periodontitis. Ann Periodontol. V.4, p.53, 1999.

21 WILSON, M. \& HENDERSON, B. Virulence factors of Actinobacillus actinomycetemcomitans relevant to the pathogenesis of inflammatory periodontal diseases. FEMS Microbiology Reviews. V.17, p.365-379, 1995.

${ }^{22}$ SCHACHER, B.; BARON, F.; ROBBERG, M.; WOHLFEIL, M.; ARNDT, R.; EICKHOLZ, P. Aggregatibacter actinomycetemcomitansas indicator for aggressive periodontitis by two analysing strategies. J Clin Periodontol.V.1, p.18, 2007.

MITCHELL, R.G. \& GILLEPSI, E. Bacterial endocarditis due to an actinobacillus. J Clin Pathol. V.17, p.511-512, 1964.

24 LÓPEZ, N.J.; SOCRANSKY, S.; SILVA, I.; JAPLIT, M.R.; HAFFAJEE, A.D. Effects of metronidazole plus amoxicillin as the only therapy on the microbiological and clinical parameters of untreated chronic periodontitis. $J$. Clin. Periodontol. V.33, p.648-660, 2006. 
25 UMEDA, M.; TAKEUCHI, Y.; NOGUCHI, K.; HUANG, Y.; KOSHY, G,; ISHIKAWA, I. Effects of nonsurgical periodontal therapy on the microbiota. Periodontol 2000. V.36, p.98-120, 2004.

26 ACKROYD, R.; KELTY, C.; BROWN, N.; REED, M. The history of photodetection and photodynamic therapy. Photochem Photobiol. V.74, p.656669, 2001.

27 SARKAR, S. \& WILSON, M. Lethal photosensitization of bacteria in subgingival plaque from patients with chronic periodontitis. J Periodont Res. V.28, p.204-210, 2003.

28 SHIBLI, J.A.; MARTINS, M.C.; NOCITI, F.H.; GARCIA, V.G.; MARCANTONIO JR., E. Treatment of ligature-induced peri-implantitis by lethal photosensitization and guided bone regeneration: a preliminary histologic study in dogs. J Periodontol. V.74, p.338-345, 2003.

GARCEZ, A.S.; NÚÑEZ, S.C.; LAGE-MARQUES, J.L.; JORGE, A.O.C.; RIBEIRO, M.S. Efficiency of $\mathrm{NaOCl}$ and laser-assisted photosensitization on the reduction of Enterococcus faecalis in vitro. Oral Surg Oral Med Oral Pathol Oral Radiol Endod. V. 102, p.e93-e98, 2006. 
${ }^{30}$ WAINWRIGHT M. Non-porphyrin photosensitisers in biomedicine. Chem Soc Rev. V. 25, p.351-358, 1996.

31 CASTANO, A.P.; DEMIDOVA, T.N.; HAMBLIN, M.R. Mechanisms in photodynamic therapy. I. Photosensitizers, photochemistry and cellular localization. Photodiagn. Photodyn. Ther. V.1, p.279-293, 2004.

${ }^{32}$ SCHAFER, M.; SCHMITZ, C.; FACIUS, R.; HORNECK, G.; MILOW, B.; FUNKEN, K.H.; ORTNER, J. Systematic study of parameters influencing the action of rose bengal with visible light on bacterial cells: comparison between the biological effect and singlet-oxygen production. Photochem. Photobiol. V.71, p.514-523, 2000.

${ }^{33}$ BHATTI, M.; MACROBERT, A.; MEGHJI, S.; HENDERSON, B.; WILSON, M. A study of the uptake of toluidine blue $O$ by Porphyromonas gingivalis and the mechanism of lethal photosensitization. Photochem. Phottobiol. V.68, p.849852, 1998. 
${ }^{34}$ GAD, F.; ZAHRA, T.; HASAN, T.; HAMBLIN, M.R. Effects of growth phase and extracellula slime on photodynamic inactivation of gram-positive pathogenic bactéria. Antimicrob. Agents Chemother. V.48, p.2173-2178, 2004.

35 TEgOS, G.P. \& HAMBLIN, M.R. Phenothiazinium antimicrobial photosensitizers are substrates of bacterial multidrug resistance pumps. Antimicrob. Agents Chemother.V.50, p.196-203, 2006.

${ }^{36}$ WAINWRIGHT M. Photodynamic antimicrobial chemotherapy (PACT) $-J$ Antimicrob Chemother. V.42, p. 13-28, 1998.

${ }^{37}$ PHOENIX, D.A.; SAYED, Z; HUSSAIN, S.; HARRIS, F.; WAINWRIGHT, M. The phototoxicity of phenothiazinium derivatives against Escherichia coli and Staphylococcus aureus. FEMS Immunol. Méd. Microbiol. V. 39, p.17-22, 2003.

38 ALMEIDA, J.M.; THEODORO, L.H.; BOSCO, A.F.; NAGATA, M.J.H.; OSHIIWA, M.; GARCIA, V.G. Influence of photodynamic therapy on the development of ligature-induced periodontitis in rats. J. Periodontol. V.78, p.566-575, 2007. 
${ }^{39}$ SOUZA, S.C.; JUNQUEIRA, J.C.; BALDUCCI, I.; KOGA-ITO, C.Y.; MUNIN, E.; JORGE, A.O.C. Photosensitization of different Cândida species by low power laser light. Photochem. Phottobiol B. V.83, p.34-38, 2006.

40 ZHANG, L.Z. \& TANG, G.Q. The binding properties of photosensitizer methylene blue to herring sperm DNA: a spectroscopy study. J Photochem Photobiol B: Biol. V.74, p.119-125, 2004.

"I MEISEL, P. \& KOCHER, T. Photodynamic therapy for periodontal diseases: State of the art. Photochem. Phottobiol B.V.79, p.159-170, 2005.

${ }^{42}$ RIBEIRO, M.S.; GROTH, E.B.; YAMADA JUNIOR, A.M.; GARCEZ, A.S.; SUZUKI, L.C.; PRATES, R.A.; NÚÑEZ, S.C. TERAPIA FOTODINÂMICA ANTIMICROBIANA. APLICAÇÕES NA ODONTOLOGIA. Livro virtual - 230 ClOSP. Capitulo 07, São Paulo, 2005.

${ }^{43}$ DOBSON, J. \& WILSON, M. Sentsitization of oral bactéria in biofilms to killing by light from a low-power laser. Arch. Oral Biol. V.37, p.883-887, 1992.

${ }^{44}$ WILSON, M.; DOBSON, J.; HARVEY, W. Sensitization of oral bactéria to killing by low-power laser radiation. Curr. Microbiol. V.25, p.77-81, 1992. 
45 WILSON, M.; DOBSON, J.; SARKAR, S. Sensitization of Periodontopathogenic Bacteria to Killing by Light from a Low-Power Laser. Oral Microbiology and Immunology. V.8, p.182-187. 1993.

${ }^{46}$ KÖNIG, K.; TESCHKE, M.; SIGUSCH, B.; GLOCKMANN, E.; EICK, S; PFISTER, W. Red light kills bactéria via photodynamic action. Cell Mol Biol. V.46, p.1297-1303, 2000.

${ }^{47}$ KOMERIK, N.; NAKANISHI, H.; MACROBERT, A.J.; HENDERSON, B.; SPEIGHT, P.; WILSON, M. In Vivo of Porphyromonas gingivalis by Toluidine Blue-Mediated Photosensitization in an Animal Model. Antimicr Agents Chemother. V.47, p.932-940, 2003.

${ }^{48}$ MATEVSKI, D.; WEERSINK, R.; TENENBAUM, H.C.; WILSON, B.; ELLEN, R.P.; LÉPINE, G. Lethal photosensitization of periodontal pathogens by a redfiltered Xenon lamp in vitro. J Periodontal Res. V.38, p.428-435, 2003.

49 OLIVEIRA, R.R.; SCHWARTZ-FILHO, H.O.; NOVAES JR., A.B.; TABA JR., M. Antimicrobial photodynamic therapy in the non-surgical treatment of aggressive periodontitis: A preliminary randomized controlled clinical study. J. Perodontol. V.78, p.965-973, 2007. 
${ }^{50}$ GONÇALVES, P.F.; NOGUEIRA FILHO, R.; SALLUM, E.A.; SALLUM, A.W.; NOCITI JUNIOR, F.H. Immunosuppressant therapy and bone loss in ligatureinduced periodontitis--a study in rats. Pesqui Odontol Bras. V.17, p.46-50, 2003

51 SCHREINER, H.C.; SINATRA, K.; KAPLAN, J.K.; FURGANG, D.; KACHLANY, S.C.; PLANET, P.J. Tight-adherence genes of Actinobacillus actinomycetemcomitans are required for virulence in a rat model. PNAS. V.100, p.7295-7300, 2003.

52

KUBONIWA, M.; AMANO, A.; KIMURA, K.R.; SEKINE, S.; KATO, S.; YAMAMOTO, Y.; OKAHASHI, N.; LIDA, T.; SHIZUKUISHI, S. Quantitative detection of periodontal pathogens using real-time polymerase chain reaction with TaqMan probes. Oral Microbiology Immunology. V.19, p.168-176, 2004.

${ }^{53}$ MERCHAT, M.; SPIKES, J.D.; BERTOLONI, G.; JORI, G. Studies on the mechanism of bacteria photosensitization by meso-substituted cationic porphyrins. J. Photochem. Photobiol. B: Biol. V.35, p.149-157, 1996.

54 DÖRTBUDAK, O.; HAAS, R.; BERNHART, T.; MAILATH-POKORNY, G. Lethal photosensitization for decontamination of implant surfaces in the treatment of peri-implantitis. Clin Oral Imp/ Res. V.12, p.104-108, 2001. 
${ }^{55}$ PFITZNER, A.; SIGUSCH, B.W.; ALBRECHT, V.; GLOCKMANN, E. Killing of periodontopathogenic bacteria by photodynamic therapy. J Periodontol. V.75, p.1343-1349, 2004.

${ }^{56}$ NÚÑEZ, S.C. Estudo da dinâmica de fotodegradação e agregação das fenotiazinas azul de metileno e azul de orto toluidina com relação à eficiência fotodinâmica. Tese de doutorado, IPEN/CNEN, 2007. •

${ }^{57}$ GROSSI, S. G. \& GENCO, R. J. Periodontal disease and diabetes mellitus: a two-way relationship. Annals of Periodontology. V.3, p.51-61, 1998.

${ }^{68}$ MERCHANT, A.T.; PITIPHAT, W.; AHMED, B.; KAWACHI, I.; JOSHIPURA, K. A prospective study of social support, anger expression and risk of periodontitis in men.JADA. V.134, p.1591-1595, 2003. 